Ks. Stanisław LONGOSZ

(Lublin, KUL)

\title{
NAZWY OETARZA CHRZEŚCIJAŃSKIEGO W LITERATURZE PATRYSTYCZNEJ
}

Ołtarz to najogólniej - wydzielone miejsce, na którym składa się ofiary krwawe i bezkrwawe, z którego kieruje się modlitwy do bóstwa. Znajdował się w każdej wyżej rozwiniętej kulturze, miał rozmaite kształty i nazwy, przypisywano mu zawsze wyjątkową godność i znaczenie, a nierzadko stanowił też symbol czegoś lub kogoś. W klasycznym języku greckim określano go najczęś-

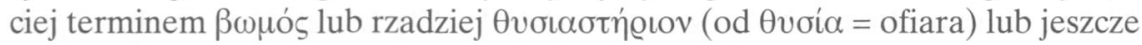
rzadziej $\mathfrak{\varepsilon} \sigma \chi \alpha \dot{\alpha} \alpha$ (= ognisko domowe, ognisko do ofiar), a na orchestrze teatru $\theta v \mu \varepsilon ́ \lambda \eta ;$ w języku łacińskim natomiast przeważnie ara (od arere - schnąć, palić), o wiele rzadziej altare (od altus $=$ wysoki, lub adolere $=$ palić $)$, najczęściej w liczbie mnogiej-altaria ${ }^{1}$. W przedchrześcijańskim świecie pogańskim panowało przekonanie o obecności bóstwa na ołtarzu: od momentu dedykacji, której dokonywano poprzez modlitewną formułę, namaszczenie lub pierwszą ofiarę, ołtarz stawał się siedzibą bóstwa oraz mógł uświęcać składane na nim dary i przedmioty. Obchodząc go, dotykając lub całując można było z niego zaczerpnąć uświęcającej mocy. Uciekając się pod jego opiekę ścigany skazaniec

${ }^{1}$ O różnej częstotliwości ich stosowania zob. Thesaurus linguae Latinae, Lipsiae 1900, t. 1, 1725-1729 (altaria), t. 2, Lipsiae 1906, 382-389 (ara). Pochodzenie terminu altaria starał się wyjaśnić w II wieku Festus, De verborum significatione, Lipsiae 1880, s. 29: „Altaria ab altitudine dicta sunt, quod antiqui diis superis in aedificiis a terra exaltatis sacra faciebant, diis terrestribus in terra, diis infernalibus in effossa terra". Natomiast biskup św. Izydor z Sewilli w VII wieku tak oto wyjaśniał pochodzenie nazw altare i ara, zob. Etymologiae XV 4, 13-14, PG 82, 545: „Aram quidam vocatam dixerunt, quod ibi incensae victimae ardebant, alii aras dicunt a precationibus id est quas Graeci

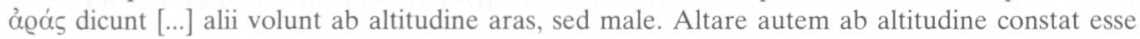
nominatum, quasi alta ara". Serwiusz zaś w swoich Scholiach do Eneidy (II 515) starał się wyjaśnić różnice semantyczne tych terminów: altaria należały do bóstw niebieskich, arae - podziemnych: „Superorum arae sunt et altaria, inferorum tantum arae”, a w innym miejscu (III 305): ,mortuorum arae, deorum altaria dicuntur". W praktyce jednak starożytni terminów tych używali raczej zamiennie (co czynił również Serwiusz) jako synonimów. Inaczej wyjaśniał tę różnicę w XII wieku Honoriusz z Autun ( $† 1150$ ), Gemma animae I 122, PL 172, 584A: „Haec autem differentia est inter altare et aram, quod altare quasi alta res vel alta ara dicitur, in quo sacerdotes incensum adolebant. Ara vero quasi area, id est piana vel ab ardore dicitur, eo quod in ea sacrificia ardebant. Ara enim Graece dicitur, Latine imprecatio". 
uzyskiwał prawo azylu. Był on również poręczycielem składanych przysiąg, jeśli przysięgający dotykał go ręką. Przed nim składano przysięgi małżeńskie, zawierano traktaty pokojowe lub od złożenia ofiary na nim wyruszano do wojen ${ }^{2}$.

W Piśmie Świętym Starego Testamentu nazwa ołtarz (hebr. mizbeah) występuje ok. 390 razy. W jego przekładzie greckim, czyli Septuagincie ${ }^{3}$, dla

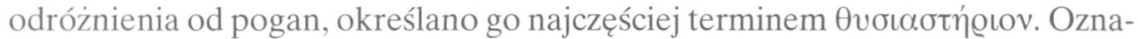
czając w sensie dosłownym miejsce składania ofiar, jako wyrazu czci należnej Bogu, ołtarz świątynny był dwojaki: Ołtarz Całopalenia - wykonany z drzewa akacjowego i pokryty miedzianymi blachami (Wj 27, 1-8; 38, 1-7) oraz Ołtarz Kadzenia - również z drzewa akacjowego, ale pokryty złotymi blachami, na którego wierzchu widniała złota korona, a w kątach sterczały cztery złote rogi, będące uosobieniem mocy Bożej oraz skuteczności modlitw i ofiar; codziennie rano kapłani palili na nim kadzidło (Wj 30, 1-10; 37, 25-29; 30, 7-9). Oprócz tych ołtarzy świątynnych w okresie patriarchalnym, jak i w czasach późniejszych, istniał zwyczaj budowania tzw. ołtarzy upamiętnienia ważniejszych zdarzeń historycznych (por. Rdz 12, 7-8; 13, 4 i 18; 26, 25; 35, 1; Wj 17, 15; Joz 22, 22-29). Według Prawa Mojżeszowego (Wj 20, 24) Izraelici mieli obowiązek budowania tego rodzaju ołtarzy w postaci nasypu ziemnego lub z kamienia nieciosanego (Wj 20, 25; Pwt 27, 5; Joz 8, 31; 1Krl 4, 47; 1Krn 18, 30-32) z zakazem budowania stopni ołtarza (Wj 20, 26); patriarchowie budowali chętnie ołtarze w cieniu drzew ( $\operatorname{Rdz} 12,6-8 ; 13,18)$ lub na wzgórzach ( $\mathrm{Rdz}$ $22,9 ; 31,54)$, a najstarszym z nich, wspominanym w Biblii zdaje się być ołtarz Noego $(\mathrm{Rdz} 8,20)$. W przeciwieństwie do ościennych narodów pogańskich, które budowały przeważnie ołtarze kamienne lub ciosane w skale, Izraelici dla uniknięcia ich zwyczajów, budowali je, zwłaszcza później, drewniane, w formie stołowej, choć nazwę stół na określenie ołtarza starotestamentalnego spotykamy tylko dwukrotnie (Ez 39, 20; Ml 1, 7 i 12) $)^{4}$.

Wszystkie przypomniane wyżej odwieczne treści i zwyczaje, dotyczące ołtarza, zwłaszcza starotestamentalne, wpłynęły również w większym lub mniejszym stopniu, na pojęcie ołtarza chrześcijańskiego, na jego nazewnictwo, znaczenie i symbolikę. W niniejszym przyczynku chcemy przypomnieć, jak autorzy wczesnochrześcijańscy od I-VIII wieku, czyli najogólniej Ojcowie Kościoła, nazywali ołtarz chrześcijański, na którym składano bezkrwawą ofiarę eucharystyczną.

${ }^{2}$ Por. Reisch, Altar, RE I/2, 1640-1691; L. Ziehen, Altar (griechisch-römisch), RACh I 310329; K. Galling, Altar (orientalisch), tamże, s. 329-334; E. Saglio, Ara, DS I/1 347-353.

${ }^{3}$ Por. Septuaginta, id est Vetus Testamentum iuxta LXX interpretes, ed. A. Rahlfs, I-II, 9. Auflage, Stuttgart 1971.

${ }^{4}$ Por. K. Galling, Der Altar in den Kulturen des Alten Orients, Berlin 1925; H. Wiener, The Altars of the Old Testament, Leipzig 1927; LThK I 369-370; Podręczna Encyklopedia Biblijna, II, Poznań 1960, 184-185. 


\section{W NAJSTARSZYM PIŚMIENNICTWIE CHRZEŚCIJAŃSKIM}

Na nazewnictwo ołtarza chrześcijańskiego w decydujący sposób wpłynęła Biblia. W jej wersji greckiej Starego Testamentu, czyli w Septuagincie, którą Ojcowie Kościoła powszechnie się posługiwali (gdyż poza nielicznymi wyjątkami nie znali języka hebrajskiego), ołtarz hebrajski, jak zaznaczaliśmy wyżej,

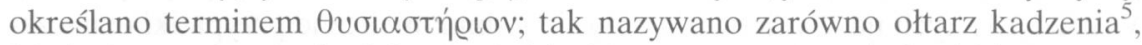
jak i ołtarz całopalenia, jak również każdy w ogóle ołtarz hebrajski. Autorzy ksiąg biblijnych Nowego Testamentu przejęli tę nazwę z Septuaginty. Na 24 przypadki występowania terminu „ołtarz” w Nowym Testamencie, aż 23 razy

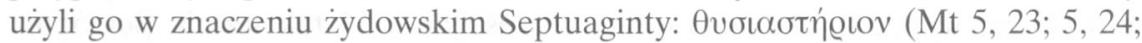
23, 18; 23, 19; 23, 35; Łk 1, 11; 11, 51; Rz 11, 3; 1Kor 9, 13; 1Kor 10, 18; Hbr 7, $13 ; 13,10)$, nawet przy określaniu ołtarza niebiańskiego, widzianego przez Jana Ewangelistę (Ap 6, 9; 8, 3; 8, 5; 9, 13;11, 1; 14, 18; 16, 7) ${ }^{6}$, tylko raz używanego w języku klasycznym terminu $\beta \omega \mu$ ó, którym św. Paweł nazywa napotkany w Atenach ołtarz nieznanego boga: „oglądając wasze świętości

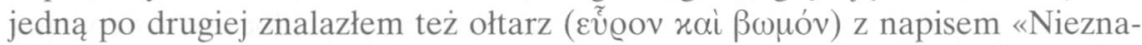
nemu bogu»" (Dz 17, 23). Co więcej, wśród tych 23 zastosowań terminu

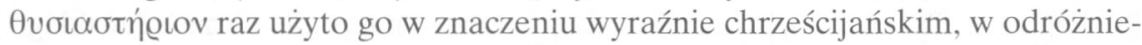

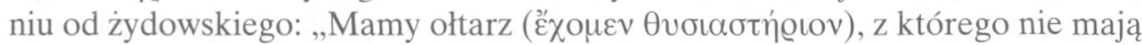
prawa spożywać ci, którzy służą przybytkowi” (Hbr 13, 10). Jest tu jasno zaznaczone, że z ofiar składanych na ołtarzu chrześcijańskim nie mają prawa korzystać czciciele dawnej świątyni: chrześcijanie mają swój ołtarz i swoją ofiarę - tę krzyżową, w której Jezus składa się bezkrwawo jako ofiara przebłagalna - z której nie mogą spożywać kapłani żydowscy. Trzeba tu też dodać, że na oznaczenie ołtarza chrześcijańskiego św. Paweł użył raz wyrażenia „stół Pana”, w odróżnieniu od ołtarza pogańskiego - „stołu demonów” (1Kor 10, 21): „Nie możecie pić z kielicha Pana i z kielicha demonów; nie możecie

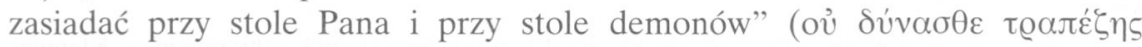

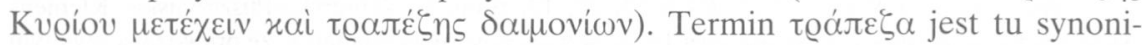

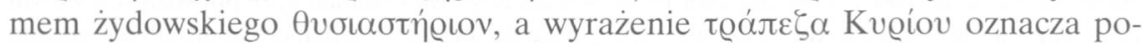
karm eucharystyczny, złożony z Ciała i Krwi Pana, spoczywający na stole-

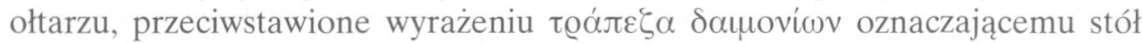
z ofiarami pogańskimi.

Przechodząc teraz do autorów wczesnochrześcijańskich, to zaraz na wstępie trzeba zaznaczyć, że wszyscy, zwłaszcza najstarsi, zarówno greccy jak i łacińscy, gdy mówili o celebrowanej Ofierze eucharystycznej na ołtarzu, skrzętnie uni-

${ }^{5}$ Rzecz ciekawa, że jeszcze po latach Józef Flawiusz (37-94) określi ten ołtarz pogańskim

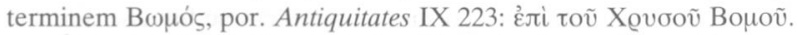

${ }^{6}$ Por. G. Kittel, Theologisches Wörterbuch zum Neuen Testament, III, Stuttgart 1938, 182-183

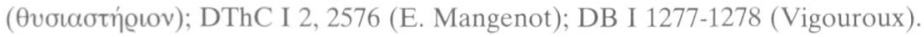


kali, ze względu na idololatrię, wszelkich wyrażeń, które mogłyby przypominać

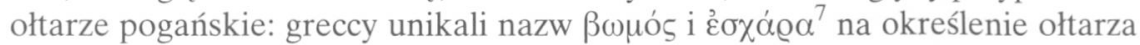

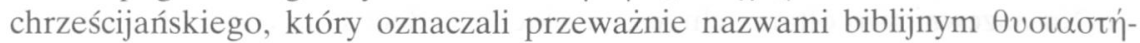
@ıov i $\varrho \alpha ́ л \varepsilon \zeta \alpha$ z różnymi przymiotnikami i przydawkami; podobnie autorzy łacińscy zamiast dotychczasowego pogańskiego określenia ara, używali nazw altare (w późniejszej łacinie też altarium) lub mensa z jakąś przydawką. W każdym z tych nazewnictw zdarzały się jednak nieliczne przypadki oznaczania także ołtarza chrześcijańskiego tradycyjnymi, przyjętymi przez wieki pogańskimi terminami $\beta \omega \mu$ ós lub ara, bo nie od razu przyzwyczajono się do nowego nazewnictwa, jakkolwiek przydawkami lub kontekstem wskazywano, że i w tym wypadku chodzi o ołtarz chrześcijański. I tak termin $\beta \omega \mu$ ó określenie ołtarza chrześcijańskiego, przenośnie lub w sposób ogólny spotykamy u Klemensa Aleksandryjskiego († 212), który pisał, że „prawdziwie świę-

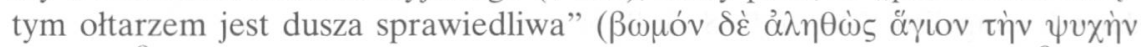
$\delta^{\prime}(x \alpha \iota \alpha v)^{8}$; w podobnym znaczeniu użył tego terminu Orygenes $(† 254)^{9}$ i Me-

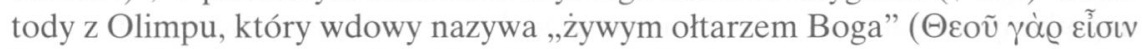

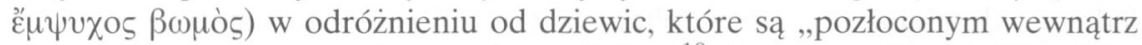
ołtarzem" (

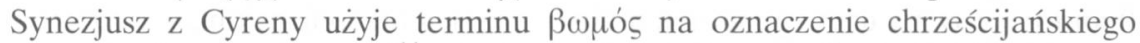
ołtarza Ofiary bezkrwawej ${ }^{11}$, choć w pozostałych wypadkach będzie go ozna-

${ }^{7}$ G.W.H. Lampe w swoim słowniku A Patristic Greek Lexicon nie wymienia już nawet tego terminu; zob. J. Braun, Der christliche Altar in seiner geschichtlichen Entwicklung, Bd. 1, München 1924, 21-32 (Die Namen des Altares); DACL I/2 3155-3189; DThC I/2 2575-2578; G.W.H.

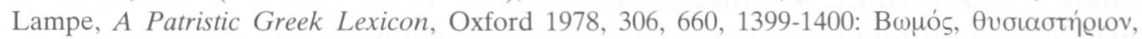

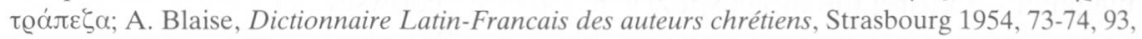
525: altare, altarium, ara, mensa; J.P. Kirch - Th. Klauser, Altar III: christlich, RACh I 334-354; F.J. Dölger, Die Heiligkeit des Altars und ihre Begründung im christlichen Altertum, ACh 2 (1930) 161-184; J.S. Pasierb, Ottarz chrześcijański: historia i symbolika, STV 6 (1968) nr 2, $17-27$.

${ }^{8}$ Por. Stromata VII 6, 32, 5, GCS 17, 24, 17, tłum. J. Niemirska-Pliszczyńska: Klemens Aleksandryjski, Kobierce, II, Warszawa 1994, 242: „Kiedy my powiadamy, że prawdziwie świętym ołtarzem jest dusza sprawiedliwa i że wznoszącym się do tego ołtarza dymem ofiarnym jest zbożna modlitwa, to nie chcą nam wierzyć".

${ }^{9}$ Por. Contra Celsum VII 17, GCS 10, 234 lub PG 11, 1541, tłum. S. Kalinkowski: Orygenes, Przeciw Celsusowi, Warszawa 1986, 391: „Celsus twierdzi, że nie chcemy wznosić ołtarzy, posągów i świątyń [...]. Nie rozumie, że dusza każdego sprawiedliwego człowieka jest dla nas ołtarzem

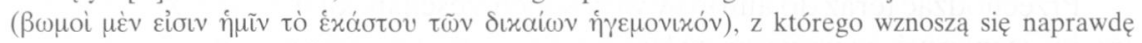
duchowe wonności - modlitwy pochodzące z czystego sumienia”.

${ }^{10}$ Por. Symposion V 8, 130, SCh 95, 160, tłum. S. Kalinkowski, PSP 24, 62: „Ottarz powleczony brązem możemy porównać do starców i wdów, bo one są żywym ołtarzem Bożym, na którym składamy Panu młode zwierzęta, dziesięciny i dobrowolne ofiary [...] natomiast ołtarz pozłocony wewnątrz, to ci którzy żyją w dziewictwie".

${ }^{11}$ Por. Catastasis 1, PG 66, 1573B: „Dei minister ego sum ac sacrificus ac fortasse animam ipsam sacrificare illi me convenit. Neque vero aram illam incruentam (

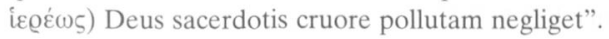




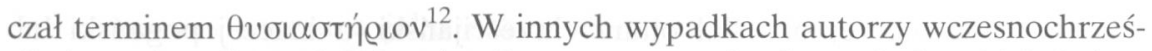
cijańscy używali terminu $\beta \omega \mu$ ó albo na oznaczenie ołtarzy żydowskich (mimo iż Septuaginta określała je terminem $\theta v \sigma \iota \alpha \sigma \tau \eta ́ @ ı v v)^{13}$, albo pogańskich ${ }^{14}$, albo przenośnie - złych lub grzesznych w odróżnieniu od chrześcijańskich ${ }^{15}$.

Podobnie na Zachodzie, twórca łaciny chrześcijańskiej - Tertulian, który choć przeważnie używał terminu altare, altaria, 9 razy posłużył się terminem ara na oznaczenie ołtarza pogańskiego ${ }^{16}$, jeden raz odniósł go też do ołtarza chrześcijańskiego, z którego spożywa się Ciało i Krew Pańską: „Czy twój post stacyjny nie stanie się uroczystszy, jeśli zajmiesz miejsce przy ołtarzu Bożym (si ad aram Dei steteris)? Gdy przyjmujesz Ciało Pańskie i masz je jeszcze, to nie przeszkadza jedno drugiemu - udział w Ofierze i spełnienie obowiązków"17. Z kontekstu wypowiedzi jasno wynika, że chodzi o ołtarz eucharystyczny, który $\mathrm{w}$ innych miejscach nazywał przeważnie altare ${ }^{18}$.

${ }^{12}$ Por. tamże, PG 66,15720: „Najpierw wstąpię do świątyni Bożej, potem okrążę ołtarz

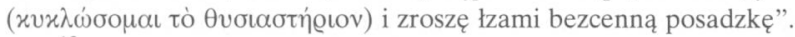

13 Por. np Ps-Eustathius Antiochenus, Commentarius in Hexaemeron, PG 18, 764D [o ołtarzu

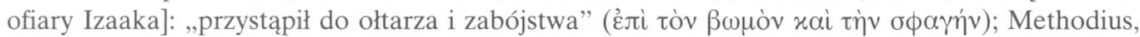
Symposion X 13, 289, SCh 95, 316, tłum. S. Kalinkowski, PSP 24, 103 [o ołtarzu ofiarnym córki Jeftego: Sdz 11, 29-40]: „Jefte swą córkę, co męża nie znała, zabił Bogu składając w ofierze na

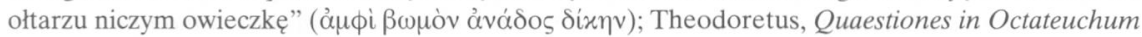
Jos. q. 19, PG 80, 480C [o ołtarzu wzniesionym przez Jozuego]: ,zanim przekroczyli rzekę, zbudo-

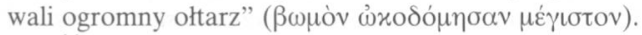

${ }^{14}$ Por. Clemens Romanus, Epistola ad Corinthios 25, 4, SCh 167, 144, thum. A. Swiderkówna, BOK 10, 63: „Tutaj w jasny dzień, na oczach wszystkich, podlatuje ołtarz słońca” (ì $\lambda$ íov $\beta \omega \mu$ òv); Hippolytus, De Christo et antichristo 49, PG 10, 769A: „Antioch Epifanes [...] wydał dekret, aby na

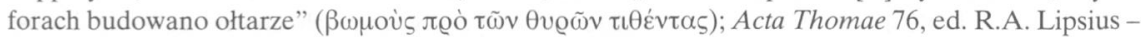
M. Bonnet, s. 191, 16, tłum. M. Starowieyski, ANT II/1, 636: „[szatan] i ja znajduję odpoczynek w zabójstwie, w cudzołóstwie, w ofiarach i libacjach wina, które mają miejsca na pogańskich ołtarzach".

15 Por. Joannes Chrysostomus, In Joannem hom. 65, 3, PG 59, 364B: „Czy nie widzisz, jakie

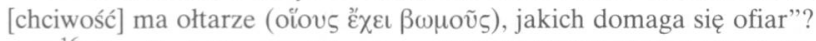

${ }^{16}$ Por. Tertullianus, Ad nationes I 10, $17-18$ i 27, CCL 1, 25-26, tłum. E. Stanula, PSP 29, 58-59: „Budujecie takie same ołtarze bogom [exstruitis aras deis] i zmarłym [...]. Ich ołtarze [Izydy i Serapisa] zostały zburzone z polecenia senatu (eorumque aras a senatu deiectas) [...] senat zakazał odbudowy ołtarzy (senatus [...] aras institui prohibuit); tamże II 15, 4, CCL 1, 70, PSP 29, 96: „ci którzy posiadają na tych samych miejscach swe ołtarze i świątynie (in iisdem locis aras vel aedes habent) płacą pewną zapłatę”; Apologeticum 6, 8, CCL 1, 98, tłum. J. Sajdak, POK 20, 31: „Konsulowie Pizo i Gabiniusz - na pewno nie chrześcijanie - po zburzeniu ich ołtarzy (eversis aris eorum); tamże 23, 5, CCL 1, 131, POK 20, 112: „którzy oddychając nad ołtarzami (aris inhalantes) z thuszczu ofiarnego boskiego ducha otrzymują"; De pallio 1, 2, CCL 2, 734: „post trinas Pompei aras”; De idololatria 11, 7, CCL 2, 1111: „fumantes aras despuet”; De spectaculis 10, 2, CCL 1, 236, PSP 5, 93 : „wśród wrzawy fletów i trąb rusza pochód od świątyń i ołtarzy” (ad scaenam a templis et aris).

17 De oratione 19, 3-4, CCL 1, 268, thum. W. Kania, PSP 5, 124.

18 Por. De oratione 11, 1, CCL 1, 263, PSP 5, 121: „w razie wywołania niezgody między braćmi lub ich obrażenia, nie pierwej przystępujemy do ołtarza Bożego (ne prius ascendamus ad altare $\mathrm{Dei})$ aż to naprawimy". 
Podobnie inaczej określał ołtarz chrześcijański, a inaczej pogański lub żydowski inny apologeta łaciński - Minucjusz Feliks ${ }^{19}$. Również późniejsi łacińscy autorzy wczesnochrześcijańscy używali powszechnie na oznaczenie ołtarza chrześcijańskiego terminu altare lub mensa, a ołtarz pogański nazywali ara. Tak czynił m.in. św. Cyprian z Kartaginy, nazywający ołtarz chrześcijański altare lub altare $D e i^{20}$, odróżniając go od pogańskiego przez nazwę ara lub ara diaboli ${ }^{21}$, tak w IV wieku Piotr Chryzolog ${ }^{22}$, a pod koniec tego wieku poeta Prudencjusz, który chociaż znał termin altare, to pisał nie tylko o arae diabolicae ${ }^{23}$, ale i ołtarz chrześcijański często nazywał ara dicata Deo ${ }^{24}$.

Wracając teraz do nazewnictwa ołtarza w pierwszych pismach chrześcijańskich, warto zaznaczyć, że w najstarszym piśmie wczesnochrześcijańskim Didache nie ma wprost mowy o ołtarzu, choć mówi się tam jasno o Eucharystii i dziękczynieniu, o ofierze publicznej, o kielichu i łamaniu chleba ${ }^{25}$, które

19 Por. Octavius 10, 2 i 4, CSEL 2, 14, tłum. M. Szarmach, PSP 44, 32: „Dlaczego więc [chrześcijanie] nie mają ołtarzy (cur nullas aras habent), świątyń żadnych, żadnych też wizerunków kultu [...]. Jedynie nędzne plemię żydowskie czciło również jedynego Boga [...] w świątyniach i na ołtarzach (templis, aris, victimis) z całym ceremoniałem i ofiarami".

${ }^{20}$ Por. Epistola 43, 5, CCL 3B, 205, thum. W. Szołdrski, PSP 1, 122: „Nie można ustawiać innego ołtarza i czynić nowego kapłaństwa, poza jednym ołtarzem i jednym kapłaństwem (aliud altare constitui aut sacerdotium novum fieri praeter unum altare et unum sacerdotium non potest); Epistola 1, 1, CCL 3B, 1, PSP 1, 27: „,ci, którzy cieszą się godnością boskiego kapłaństwa [...] powinni służyć wyłącznie ołtarzowi, ofiarom, prośbom i modlitwom (in clerico ministerio constituti non nisi altari et sacrificiis [...] vacare debeant)"; zob. też. De lapsis 8, CCL 3/1, 225, POK 19, 202.

${ }^{21}$ Por. Epistola 65, 1, CCL 3C, 427, PSP 1, 217: ,jakby to było godziwe od ołtarzy ofiarnych diabła, przystąpić do ołtarza Boga" (post aras diaboli accedere ad altare Dei); Ad Demetrianum 12, CCL 3A, 42, POK 19, 312: „Dymią wszędzie w waszych świątyniach ofiarne zgliszcza i stosy zwierzęce, a ołtarzów Boga albo nie ma wcale, albo są ukryte (et Dei altaria vel nulla sunt vel occulta)"; zob. też Ps-Cyprianus, Quod idola dii non sunt 7, CSEL 3/1, 24, POK 19, 104.

22 Por. Sermo 51, PL 52, 343, CCL 24, 285-286: „Quam diu apud vos, et non ad gentes mittam, ubi ad unius discipuli mei vocem templa corruunt, simulacra fugiunt, consumuntur arae, cedunt idola [...] commutantur in ecclesias delubra, in altaria vertuntur arae".

${ }^{23}$ Por. Peristephanon V1 34-36, CCL 126, 315, thum. M. Brożek, ŹMT 40, 242: „Tutaj Emilian sędzia grozi im męką [...] każe im cześć szatańskim oddać ołtarzom (aras daemonicas coli iubebant)".

${ }^{24}$ Por. Peristephanon XI 170, CCL 126, 375, ŹMT 40, 320: „Obok stoi Bogu poświęcony ołtarz, ta mensa, ta rozdawczyni Sakramentu" (ara dicata Deo, illa sacramenti donatrix mensa); tamże IX 100, CCL 126, 329, ŹMT 40, 261: „I ołtarz grzeją usta, i pierś kamień grobu (altar tepescit ore, saxum pectore)”; tamże V 515-518, CCL 126, 311-312, ŹMT 40, 236: „Gdy sprawiedliwy już pokój nastał, spoczynek należny szczątkom świętego dał ołtarz. Bo położone w świątyni i pod ołtarzem schowane chłoną woń ofiar niebiańskich (altar quietem debitam praestat beatis ossibus; subiecta nam sacrario imamque ad aram muneris perfusam subtus hauriunt) "; tamże X 49, CCL 126, 332, ŹMT 40, 267: „Gotował się więc bezbożnik z bezecnym wojskiem od fundamentu wywrócić i zniszczyć ołtarz (altaris aram funditus pessumdare)"; Cathemerinon VII 203, CCL 126, 42, PSP 43, 64: „To nam niesie łaskę przybytku ołtarza (altaris aram quod facit placabilem), to wiarę rozbudza w drzemiącym w nas sercu".

25 Por. Didache 9-10, SCh 248bis, 174-182, tłum. A. Świderkówna, BOK 10, 37-38. 
bez wątpienia suponują jakiś ołtarz. Z innych Ojców Apostolskich jedynie Klemens Rzymski, Ignacy Antiocheński, Polikarp ze Smyrny, Pseudo-Barna-

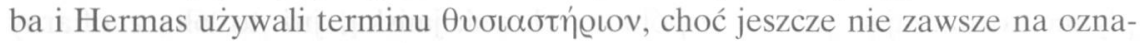
czenie konkretnego, materialnego ołtarza chrześcijańskiego. Pierwszy z nich,

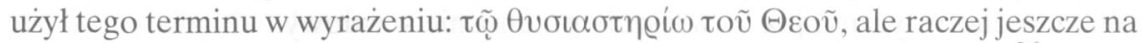
oznaczenie ołtarza żydowskiego, przy którym służyli kapłani i lewici ${ }^{26}$; on to również, jak wspominaliśmy, ołtarz pogański nazywał $\beta \omega \mu$ ó $^{27}$. Natomiast

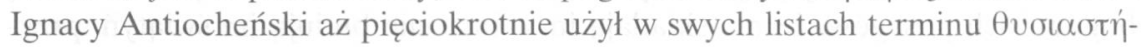
@ıv w różnych znaczeniach, w tym również po raz pierwszy na oznaczenie ołtarza eucharystycznego. Terminem tym oznaczał więc najpierw Kościół jako wspólnotę chrześcijańską, zgromadzoną na modlitwie pod kierownictwem duchownych $^{28}$, innym razem ołtarz ofiarny w ogóle, na którym ma się przelać krew męczennika ${ }^{29}$, a wreszcie ołtarz eucharystyczny, otoczony przez duchownych na czele z biskupem, składających ofiarę eucharystyczną, będącą zwornikiem całej wspólnoty ${ }^{30}$. Z kolei autor Listu Pseudo-Barnaby używa terminu

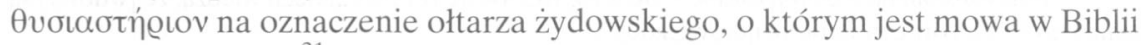
Starego Testamentu ${ }^{31}$, Hermas w swoim Pasterzu na oznaczenie ołtarza Bożego w niebie ${ }^{32}$, a Polikarp ze Smyrny po raz pierwszy przenośnie wdowy nazywa

${ }^{26}$ Por. Epistola ad Corinthios 32, 2, SCh 167, 150, BOK 10, 65: „Od Jakuba bowiem pochodzą

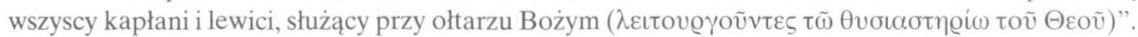

27 Por. wyżej przypis 14.

28 Por. Epistola ad Trallianos 7, 2, SCh 10, 100, BOK 10, 125: „kto jest wewnątrz wspólnoty

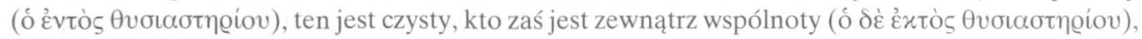
ten czysty nie jest. Znaczy to, że kto czyni coś bez biskupa, kapłanów i diakonów, ten nie ma czystego sumienia"; Epistola ad Ephesios 5, 2, SCh 10, 62, BOK 10, 114: „ten kto nie jest we wspólnocie (

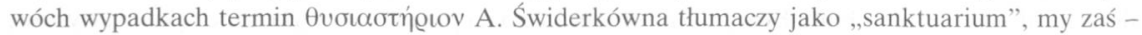
„wspólnota”.

${ }^{29}$ Por. Epistola ad Romanos 2, 2, SCh 10, 108, BOK 10, 128: „Nie próbujcie mi dać nic więcej ponad to, aby krew moją wylano na ofiarę Bogu, dopóki ołtarz jest jeszcze gotowy (

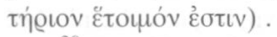

${ }^{30}$ Por. Epistola ad Philadelphios 4, 1, SCh 10, 122, BOK 10, 133: „Starajcie się uczestniczyć w jednej Eucharystii. Jedno bowiem jest Ciało Pana naszego Jezusa Chrystusa i jeden kielich, aby nas zjednoczyć z Krwią Jego, jeden ołtarz ( z kapłanami i diakonami”; Epistola ad Magnesios 7, 2, SCh 10, 86, BOK 10, 121: „Wszyscy biegnijcie jakby zjednoczyć się w jedną świątynię Bożą (

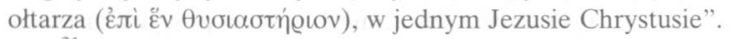

31 Por. Epistola Ps-Barnabae 7, 3 i 9, SCh 172, 130: „w ofierze za nasze grzechy, czego

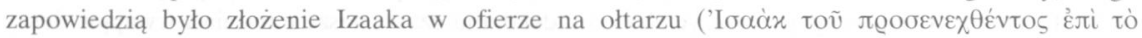

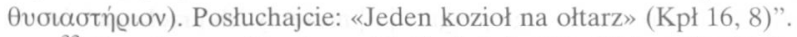

32 Por. Pastor. Mandatum X 42, 3, 2-3, SCh 53bis, 190, BOK 10, 241: „Modlitwa człowieka

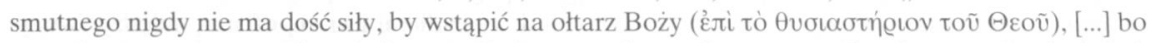

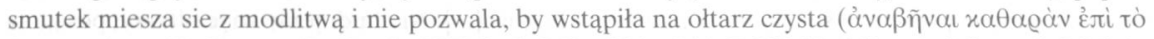

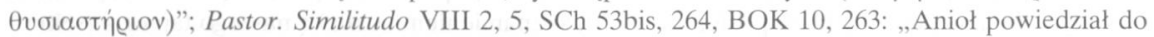

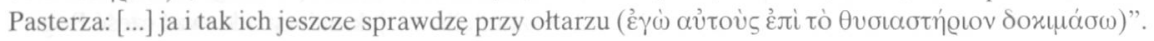


„ołtarzem Bożym”33. Z powyższych uwag widać, że w pismach Ojców Apos-

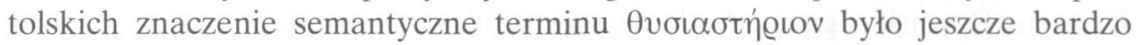
płynne, oznaczając już to wspólnotę chrześcijańską, już to ołtarz ofiarny w ogóle, zwłaszcza w Starym Testamencie, już to ołtarz Boży w niebie, już to ołtarz eucharystyczny, już to wreszcie przenośnie - wdowy.

Nieco później, apologeci chrześcijańscy broniąc swoich współbraci przed oskarżeniami ze strony pogan i żydów o ateizm i bezbożnictwo, że nie czczą bogów i ich posągów, że nie składają im ofiar i nie budują im świątyń, przyznawali, że nie mają oni faktycznie ołtarzy podobnych do ołtarzy pogańskich i żydowskich, przeznaczonych do kultu bożków i ofiar krwawych - co na Zachodzie lakonicznie wyraził Minucjusz Feliks w słowach: „Delubra et aras non habemus" 34 , a na Wschodzie m.in. Atenagoras z Aten ${ }^{35}$, a pół wieku później w dłuższym wywodzie Orygenes ${ }^{36}$ - ale zawsze podkreślali, że nie są

${ }^{33}$ Por. Epistola ad Philippenses 4, 3, SCh 10, 182, BOK 10, 157: „Niech wiedzą, że [wdowy] są

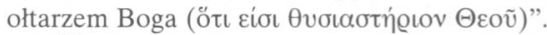

34 Por. Octavius 32, 1, CSEL 2, 45, PSP 44, 67: „Czy sądzicie, że jeśli nie mamy świątyń i ołtarzy, to ukrywamy przedmiot naszej czci? [...]. Jakąż mu świątynię wzniosę, jeśli nie może Go objąć cały ten świat, który On stworzył? Jakże śmiałbym zamknąć tak wielki ogrom majestatu w jednej kapliczce? [...]. Czyż nie lepiej, byśmy oddawali Mu cześć umysłem i składali ofiary w naszym sercu? Czyż będę składał Bogu w ofierze bydlęta i zwierzęta"?

35 Por. Legatio pro christianis 13-14, PG 6, 916 lub SCh 379, 110-112, tłum. S. Kalinkowski: Atenagoras z Aten, Prośba za chrześcijanami, Warszawa 1985, 42-43.

${ }^{36}$ Por. Contra Celsum VII 64 i VIII 17-20, PG 11, 1512 i 1540-1549, thum. S. Kalinkowski: Orygenes, Przeciw Celsusowi, Warszawa 1986, 378 i 391-394: „Jak więc jeden czyn [...] okazuje się złożony ze względu na różne poglądy i przekonania osób działających, tak samo ci, którzy nie chcą czcić bóstwa na ołtarzach, w świątyniach i przed posągami [...] postępują w ten sposób powodowani innymi przekonaniami niż Żydzi i chrześcijanie. Poganie gardzą ołtarzami i posągami wcale nie dlatego, aby nie poniżać kultu Bożego i nie przenosić go na przedmioty wykonane rękami artystów, ani dla przekonania, że w pobliżu posągów i świątyń gromadzą się złe duchy [...] chrześcijanie natomiast i Żydzi nie tylko brzydzą się świątyniami, ołtarzami i posągami bogów, ale gdy trzeba, gotowi są raczej śmierć ponieść, niż splamić grzechem swe wyobrażenie Najwyższego Boga”; VIII 17-20: „Celsus twierdzi dalej, że nie chcemy wznosić ołtarzy, posągów i świątyń, bo jak sądzi, niechęć taka jest znamieniem i oznaką naszej tajnej i sekretnej wspólnoty. Nie rozumie, że dusza każdego sprawiedliwego człowieka jest dla nas ołtarzem, z którego wznoszą się naprawdę duchowe wonności - modlitwy pochodzące z czystego sumienia [...]. Krótko mówiąc, wszyscy chrześcijanie pragną wznosić ołtarze i posągi, o których wspomniałem: nie są one bezduszne i martwe, lecz przyjmują Ducha Bożego, który jak we własnym domu w nich mieszka [...]. Kto ma ochotę, niechaj porówna opisane przeze mnie ołtarze z ołtarzami, o których mówi Celsus, niech zestawi posągi wzniesione w duszach ludzi oddających cześć Bogu z posągami wykonanymi przez Fidiasza [...] pojmie wówczas, że tamte są martwe i podlegają niszczycielskiemu działaniu czasu, nasze natomiast trwają w duszy nieśmiertelnej tak długo, jak długo dusza rozumna tego pragnie [...] możemy ich przekonać, że nie ma porównania między naszymi posągami a posągami pogańskimi, między naszymi ołtarzami a ich ołtarzami i, jeśli tak można powiedzieć, ich ołtarzami, kadzidłami i krwią ofiarną, między świątyniami w naszym pojęciu, a świątyniami martwych bogów [...]. Nie budujemy więc ołtarzy, posągów i świątyń nie dlatego, żeby takie postępowanie było znamieniem i oznaką naszego tajnego i sekretnego związku, ale dlatego, że dzięki nauce Jezusa zrozumieliśmy, jak należy oddawać cześć Bogu”. 
ateistami i bezbożnikami, bo niewidzialnego Boga czczą w sposób duchowy. Nie twierdzili również nigdy, że nie mają swoich ołtarzy, bo składali przecież bezkrwawą Ofiarę eucharystyczną, ale z obawy o posądzenie o analogiczną idololatrię, unikali skrzętnie wszelkiej terminologii ołtarzowej. Przykładem jest tu choćby św. Justyn Męczennik († 167), który choć w swojej Apologii opisuje dokładnie sprawowanie Eucharystii ${ }^{37}$, a w Dialogu z Żydem Tryfonem zaznacza, że jest ona zapowiedziana przez ofiary żydowskie i proroka Malachiasza $^{38}$, to jednak nigdzie w tym kontekście nie użył terminu „ołtarz”

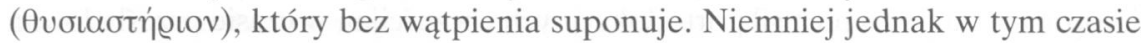
św. Ireneusz z Lyonu († 202) ucząc, że Jezus Chrystus ustanowił ofiarę, złożoną z chleba i wina, która winna być często i bez przerwy składana na ołtarzu,

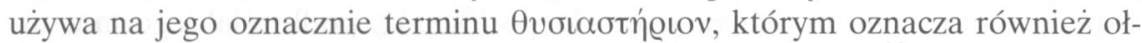
tarz w niebie, do którego docierają nasze modlitwy i prośby ${ }^{39}$.

W późniejszym okresie, kiedy chrześcijaństwo miało już pełną swobodę działania, budowania świątyń i bazylik, a w nich ołtarzy, to te ostatnie na

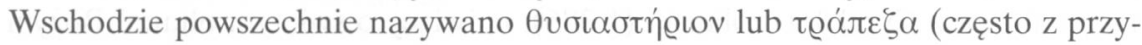
dawką), a na Zachodzie altare, mensa, a w późniejszym okresie także altarium, choć wszystkie te nazwy przybierały niekiedy i inne znaczenia.

\section{U GRECKICH OJCÓW KOŚCIOŁA}

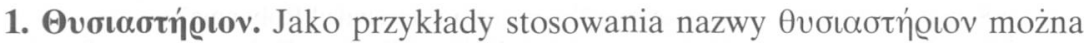
tu m.in. najpierw wymienić Euzebiusza z Cezarei († 339), który opisując poświęcenie bazyliki w Tyrze tak określał znajdujący się w niej ołtarz, nazywał go świętym i wielkim, porównywał do żydowskiego przybytku Święte Świętych i wyobrażał sobie, że staje przy nim Chrystus jako Wielki Arcykapłan wszechświata, modli się i wstawia za nami do Boga ${ }^{40}$. Tak też później czynił św. Atanazy

${ }^{37}$ Por. Apologia I 65-67, PG 6, 428-429 lub SCh 507, 302-312, thum. L. Misiarczyk, BOK 24, 254-256 lub POK 4, 75-58.

38 Por. Dialogus cum Judaeo Tryphone 41 i 117, PG 6, 564 i 745, POK 4, 166-167 i 306-308.

39 Por. Adversus haereses IV 18, 6, SCh 100, 615: „Słowo dało ludziom przykazanie składania ofiar, choć ich nie potrzebowało, aby nauczyć służyć Bogu, tak też chce, abyśmy także składali dar na ołtarzu często i bez przerwy. Jest bowiem ołtarz w niebiesiech, na który modlitwy nasze i prośby

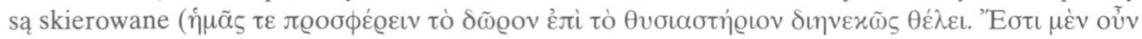

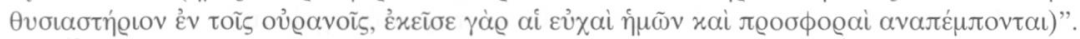

${ }^{40}$ Por. HE X 4, 68, PG 20, 877A, tłum. A. Lisiecki, POK 3, 443: „Święty zaś, wielki i jedyny

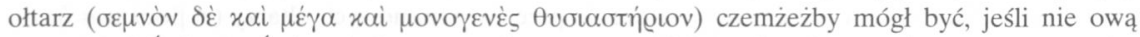
czystością i Świętem Świętych duszy wspólnego wszystkich kapłana? Przy nim stoi, po prawicy jego, Wielki Arcykapłan wszechświata, sam Jezus, jednorodzony Syn Boży, który od wszystkich wonne kadzidło i bezkrwawe oraz bezcielesne modłów ofiary przyjmuje jasnem obliczem i wyciągniętemi rękoma i składa je Ojcu niebieskiemu, a Bogu wszech rzeczy. On Sam się pierwszy modli do Niego i Sam jeden Ojcu cześć Jemu przynależną oddaje, a potem Go błaga, by był nam wszystkim łaskawy i dobry na wieki”. 
Aleksandryjski (†373), który mówił o „ołtarzu Bożym” w odbudowanej świątyni Ezdrasza ${ }^{41}$, i o ołtarzu Samarii, przy którym złorzeczył prorok z Judy w obecności Roboama ${ }^{42}$, a także o wizji św. Antoniego, który widział ołtarz

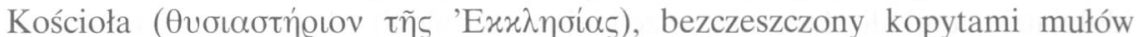

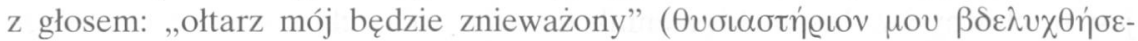
$\tau \alpha \iota)$, co się sprawdziło 2 lata później, gdy arianie napadali na kościoły i w obecności pogan ,robili z ołtarzami, co chcieli”,43. Biskup aleksandryjski znał także termin $\beta \omega \mu$ ó s, którym oznaczał ołtarze pogańskie, jakie wznoszono i doprowadzano do nich siłą ortodoksyjnych chrześcijan w czasie prześladowań w Aleksandrii ${ }^{44}$. Z Ojców Kapadockich można tu najpierw wskazać Grzegorza z Nazjanzu († 390), który objaśniając znaczenie ołtarza chrześcijańskiego, w przeciwstawieniu do ołtarza pogańskiego ( $\beta \omega \mu o ́ s)$ podkreślał jego moc uzdrawiającą oraz zaznaczał, że prawowici chrześcijanie mają tylko jeden ołtarz ${ }^{45}$; potem św. Grzegorza z Nyssy (†394), dla którego ołtarz jest symbolem jedności prawowitej zdrowej wiary ${ }^{46}$, a także Bazylego Wielkiego $(\dagger 379)^{47}$. Podobnie nazywał ołtarz Cyryl Jerozolimski (†386), mówiący o świętym ołtarzu Bożym (๕̊) tajemnice $^{48}$, autor pochodzącej z IV wieku Pasji św. Teodota, przeciwstawiają-

${ }^{41}$ Por. Apologia ad Constantium 18, PG 25, 617C, tłum. J. Ożóg, PSP 21, 177: ,zbudowali

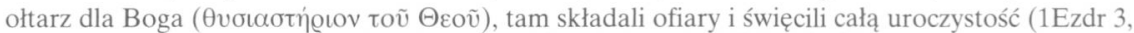
8-11).

42 Por. Apologia de fuga sua 17, PG 25, 665B, PSP 21, 197: „prorok, który złorzeczył przy

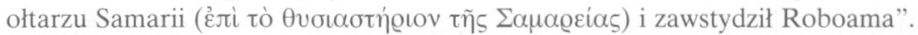

${ }^{43}$ Por. Vita Antonii 82, PG 26, 960 A lub SCh 400, 346, tłum. Z. Brzostowska: Sw. Atanazy Aleksandryjski, Żywot św. Antoniego, Warszawa 1987, 104-105.

44 Por. Apologia contra arianos 15, PG 25, 273AB: „zapowiadano im ołtarze i ofiary pogań-

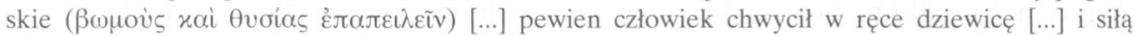

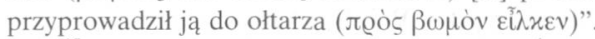

45 Por. Oratio 5, 29, PG 35, 701A, tłum.: Św. Grzegorz z Nazjanzu, Mowy wybrane, Warszawa 1967, 217: ,już nie będą plugawić krwią zbrodniczą ołtarzy uświęconych najczystszą i bezkrwawą

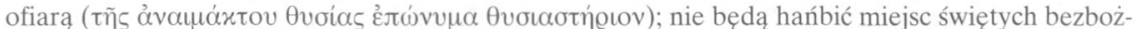

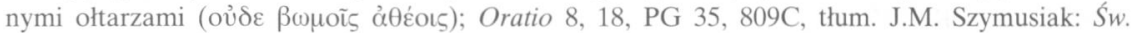

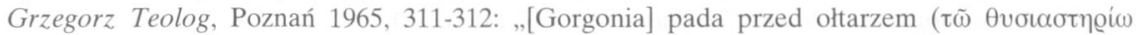

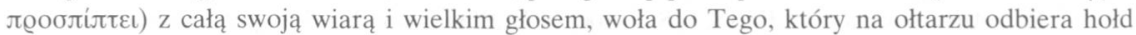

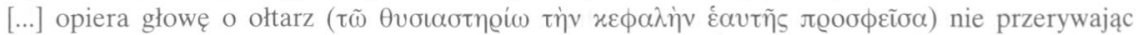
wołania strugami łez go zrasza i oświadcza, że nie opuści go i nie odejdzie, zanim zdrowia nie odzyska”; Oratio 26, 18, PG 35, 1252A, Grzegorz Teolog, s. 366: „Jak mogliście stawiać ołtarz

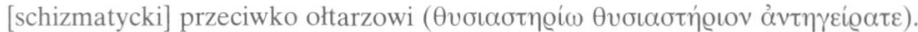

46 Por. Epistula 3, PG 46, 1024A, thum. T. Sinko: Św. Grzegorz z Nyssy, Wybór pism, War-

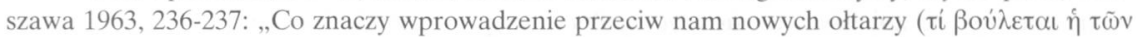

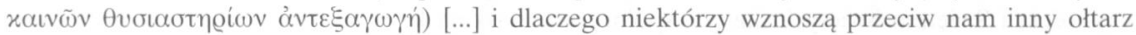

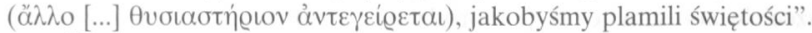

47 Por. Ps-Basilius, Historia mystagogica 5, ed. F.E. Brightman, JTS 9 (1908) 258-259.

48 Por. Catechesis 18, 32, PG 33, 1053B, tłum. W. Kania, PSP 9, 298: „macie pójść do chrztu, do świętego ołtarza Bożego ( bieskie tajemnice". 
cy pogańskiemu ołtarzowi ( $\beta \omega \mu \tilde{\omega})$ ołtarz chrześcijański ( $\theta v \sigma \iota \alpha \sigma \tau \eta \dot{\varrho} \iota v)^{49}$, czy wreszcie św. Jan Chryzostom († 407), który choć przeważnie ołtarz chrześcijań-

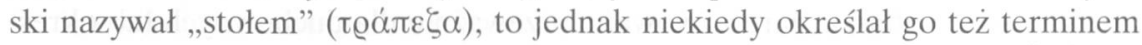

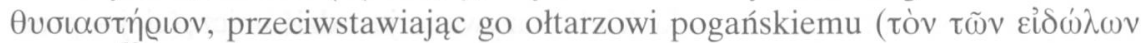
$\beta \omega \mu o ̀ v)^{50}$. Podobnie także czynił Pseudo-Dionizy Areopagita, który nazwę tę

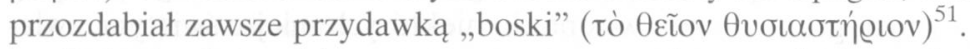

Tak również w dalszym ciągu nazywano ołtarz w niebie, na który spływają z ziemi modlitwy, umartwienia, dobre uczynki i duchowe ofiary, kierowane do $\mathrm{Boga}^{52}$. Przed tym też niebieskim ołtarzem stają, zdaniem Orygenesa, dusze ludzi zamordowanych z powodu Chrystusa i proszą o odpuszczenie grzechów dla grzeszników ${ }^{53}$; na nim składane są dusze męczenników ${ }^{54}$, na nim w otoczeniu aniołów Bóg jest uwielbiany ${ }^{55}$, jego zaś typem i obrazem jest, jak zaznacza Jan Chryzostom, materialny ołtarz ziemski ${ }^{56}$.

${ }^{49}$ Por. Passio Theodoti Ancyrani et septem cum eo virginum (18 V), 1, 4, ASS vol. Maii IV 151:

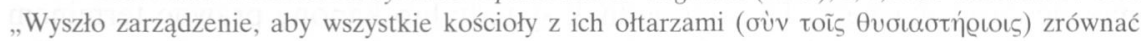

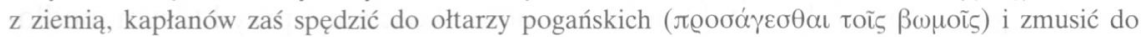
złożenia ofiary"; zob. Eusebius, HE VII 32, 23-24; H.D., La Passion de S. Théodote d'Ancyre, AnBol 22 (1903) 320-328; BS XII 309-312 (J.M. Sauget).

50 Por. In Epistolam 1 ad Corinthios hom. 24, 1, PG 61, 200A: „Jeśli pragniesz krwi, mówi [Chrystus], to nie szukaj ołtarza bożków z zabijaniem zwierząt, ale mojego ołtarza, zroszonego moją krwią ( Joannem hom. 13, 4, PG 59, 90C: „«Oleju pragnę, nie ofiary» $(\mathrm{Oz} 6,6)$. I słusznie: ów bowiem

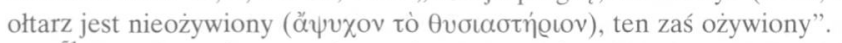

51 Por. De ecclesiastica hierarchia 5, 3, 2, PG 3, 509, thum. M. Dzielska: Pseudo-Dionizy Areopagita, Pisma teologiczne, wyd. 2, Kraków 2005, 190-191: „W czasie obrzędu święceń episkopalnych

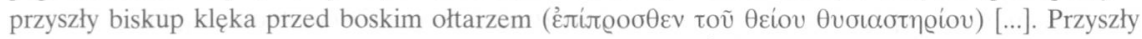

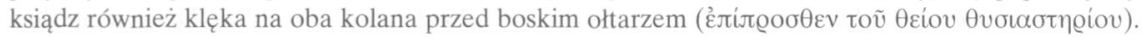

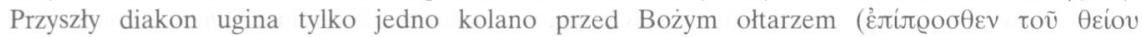

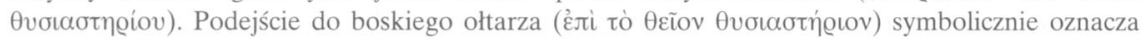
dla wszystkich, którzy dostępują święceń kapłańskich, całkowite poddanie własnego życia Bogu".

52 Por. Hermas, Pastor. Mandatum 10, 42, 3, 2, zob. wyżej przypis 32.

53 Por. Exhortatio ad martyrium 30, PG 11, 601B, tłum. S. Kalinkowski, PSP 24, 157: „Dusze

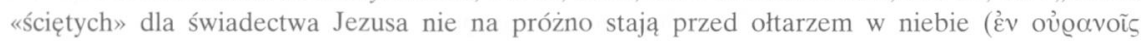

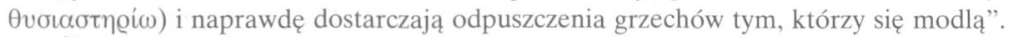

${ }^{54}$ Por. Oecumenius, Commentarius in Apocalypsin 6, 9, ed. H.G. Hoskier, Michigan 1928, 91 : „Widziałem, mówi, dusze męczenników, mające wzniosły stan: były bowiem nad nadprzyrodzonym

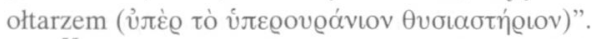

55 Por. Hesychii Fragmenta in Psalmos 112, 4, PG 93, 1329B: „Chociaż [Bóg] uwielbiany jest tutaj, to jednak Jego chwała zmierza ku niebu, gdzie ma nie ręką ludzką wykonany ołtarz (

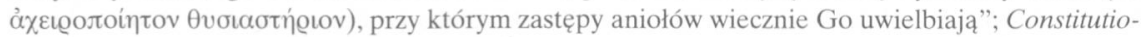
nes Apostolorum VIII 13, 3, SCh 336, 206, ŹMT 42, 246: „Módlmy się, aby tę ofiarę [...] dobry Bóg

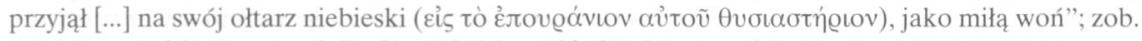
też Liturgy of St. James, ed. B. Ch., PO 26, s. 180, 27; Liturgy of St. Basil, ed. F.E. Brightman, w: Liturgies Eastern and Western, Oxford 1896, s. 319, 25.

56 Por. Joannes Chrysostomus, In Isaiam 6, 1, hom. 6, 3, PG 56, 139A: „Ów ołtarz (Iz 6, 6) jest

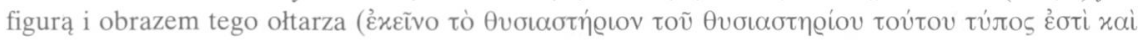




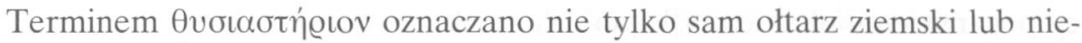
bieski, ale również, zwłaszcza w starożytnych tekstach prawnych i liturgicznych, miejsce wokół ołtarza, zarezerwowane przeważnie dla duchownych lub określonej grupy osób; miejsce to w kościele nazywane jest dziś najczęściej - prezbiterium. Widać tu niewątpliwie wpływ Starego Testamentu, którego przepisy zabraniały pewnym grupom osób wstępu do niektórych miejsc świątyni, zwłaszcza dostępu do ołtarza. Znalazło to odzwierciedlenie również w późniejszej literaturze judaistycznej ${ }^{57}$.

To właśnie miejsce, otaczające bezpośrednio ołtarz w kościele, nazywane już

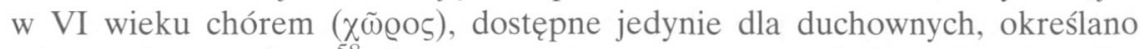
mianem $\theta v \sigma \iota \alpha \sigma \tau \eta \dot{\iota} \iota v^{58}$. Do tego miejsca, nazywanego dziś prezbiterium, Synod Laodycejski z końca IV wieku, dopuszcza jedynie duchownych, przyjmujących Komunię Świętą ${ }^{59}$, zakazując doń wstępu kobietom ${ }^{60}$, obradujący zaś 200 lat później synod trullański, nazywany też Soborem Konstantynopolitańskim III - wstępu laikom w ogóle $\mathrm{e}^{61}$; na tym terenie wolno też tylko było przyjmować dary ofiarne ${ }^{62}$. Te same jednak synody lub kanony prawne terminem

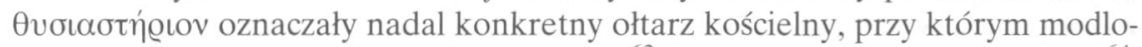
no się i sprawowano Ofiarę Eucharystyczną ${ }^{63}$; jest on również miejscem azylu ${ }^{64}$.

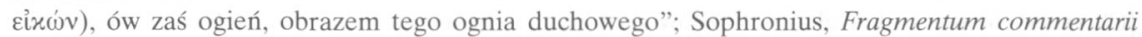

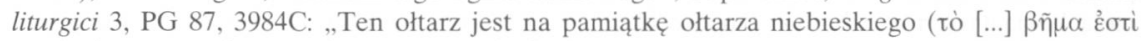

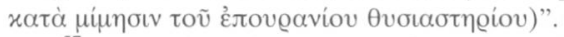

57 Por. m.in. Reliquiae Apocalypsis Baruch 2, 10 i 9, 7, ed. J. Rendel Harris: The Rest of the Words of Baruch, London 1889, 57, 72.

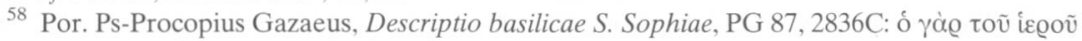

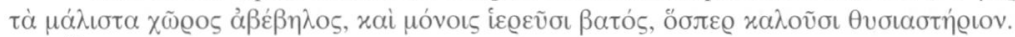

${ }^{59}$ Por. Concilium Laodicenum can. 19, ed. Hefele - Leclercq, I/2, s. 1010: „Do prezbiterium wolno wchodzić jedynie osobom duchownym i tam przyjmować Komunię Świętą (uóvols k̇̌̀ò

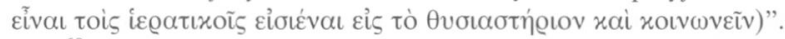

${ }^{60}$ Por. tamże can. 44, Hefele - Leclercq, I/2, s. 1020: „Kobietom nie wolno wchodzić do

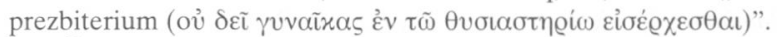

${ }^{61}$ Por. Concilium Trullanum can. 69, Mansi XI 973: „Żadnemu z laików nie wolno wstępować do świętego prezbiterium (

${ }^{62}$ Por. Palladius, Dialogus de vita S. Joannis Chrysostomi 15, PG 47, 51 lub SCh 341, 294: „Synod nakazał, aby złoto od spadkobierców Antonina przyjmować i komunikować się z nimi tylko wewnątrz prezbiterium (

${ }^{63}$ Por. Canones Apostolorum can. 3, ed. F.X. Funk, Didascalia et Constitutiones Apostolorum, Paderbornae 1905, 565: ,Jeżeli którykolwiek biskup lub prezbiter, wbrew ustaleniu Pana, złoży na

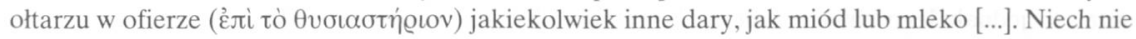

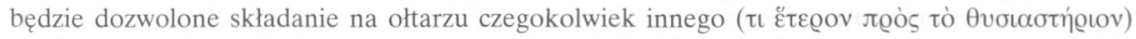
oprócz oliwy i kadzidła”; tamże can. 4, Funk s. 565: „Wszelkie inne pierwociny owoców będą

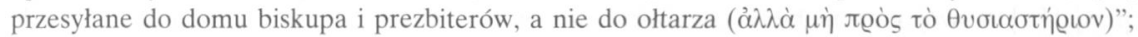
Concilium Trullanum can. 57, Mansi XI 969: „Nie przystoi przynosić do ołtarzy miód i mleko (őtı

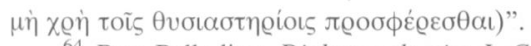

${ }^{64}$ Por. Palladius, Dialogus de vita J. Chrysostomi 6, PG 47, 23 lub SCh 341, 136: „Uciekł trzymając się ołtarza ( 
Ten to jeden konkretny ołtarz był także symbolem jedności kościelnej, którą zrywał każdy, kto budował sobie inny nowy ołtarz ${ }^{65}$.

Terminu $\theta v \sigma \iota \alpha \sigma \tau \eta \dot{\iota} \iota v$ używano w literaturze patrystycznej także przenośnie i metaforycznie, oznaczając nim, oprócz ołtarza, również inne rzeczywistości - osoby lub rzeczy: często identyfikowano go z samym Chrystusem ${ }^{66}$, nieco rzadziej oznaczano nim Jego Matkę Maryję ${ }^{67}$, założony przez Niego Kościół $^{68}$, a także, jak zaznaczaliśmy już wyżej ${ }^{69}$, szczególnie poszkodowanych życiowo - wdowy i sieroty $^{70}$.

${ }^{65}$ Por. Canones Apostolorum can. 31, Funk s. 572: „Jeśli którykolwiek prezbiter wzgardziw-

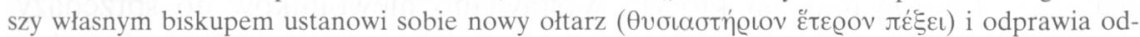
dzielne nabożeństwa [...]”; Concilium Antiochenum (341) can. 5, ŹMT 37, 136: „gdyby jakiś prezbiter albo diakon lekceważąc swojego biskupa oddalił się od Kościoła [...] ustawił własny

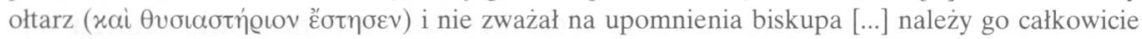
pozbawić urzędu bez prawa powrotu".

${ }^{66}$ Por. Eusebius, HE X 4, 68,PG 20, 877A, POK 3, 443: „Święty zaś wielki i jedyny ołtarz [w bazylice tyrskiej] czymże mógł być, jeśli nie ową czystością i Swiętym Świętych duszy wspólnego

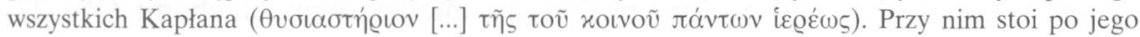
prawicy Wielki Arcykapłan wszechświata, sam Jezus - Jednorodzony Syn Boży”; Ignatius, Epistola ad Magnesios 7, 2, zob. wyżej przypis 30; Cyrillus Alexandrinus, De adoratione in Spiritu 9, PG

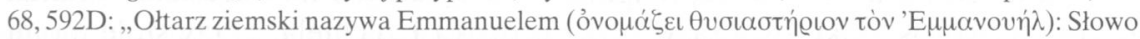
bowiem ciałem się stało”; tamże, PG 68, 648BC: „Wspominaliśmy, że złotym ołtarzem i delikatnym kadzidłem jest Chrystus ( oznaczają”; Andreas Caesariensis, Commentarius in Apocalypsin 21, PG 106, 288BC: „tym złotym

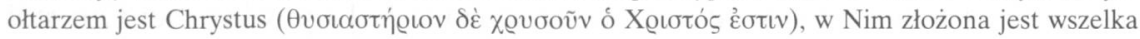
święta i działająca moc; na nim składane są ofiary wszystkich męczenników"; Ps-Dionysius Areopagita, Ecclesiastica hierarchia 4, 3, 12, PG 3, 484D, tłum. M. Dzielska, s. 183: „w istocie to sam

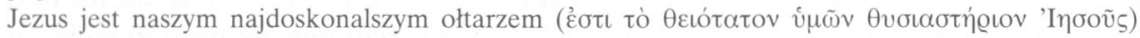
naszych konsekracji, na którym dokonuje się tearchiczne poświęcenie intelektów boskich i na którym poświęceni i mistycznie ofiarowani otrzymujemy do Niego dostęp”.

${ }^{67}$ Por. Proclus Constantinopolitanus, Oratio 6, 17, PG 65, 753B: „Jakimiż kolorami mam namalować dziewiczy obraz Maryi [...]. Jest ona sanktuarium niewinności, jest uświęconą świąty-

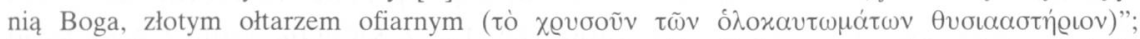
Ps-Methodius, Sermo de Simeone et Anna 14, PG 18, 381: „Tyś nam początkiem święta światła [...] najcenniejszą perłą królestwa, sednem całej ofiary, ożywionym ołtarzem chleba życia (

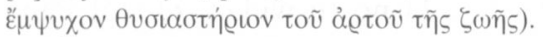

${ }^{68}$ Por. Clemens Alexandrinus, Stromata VII 6, 31, 8, PG 9, 444B, GCS 17, 23, 27-28, thum. J. Pliszczyńska II, s. 241: „,nasz ołtarz ofiarny jest ziemską wspólnotą ludzi oddanych modlitwie

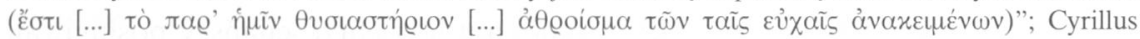
Alexandrinus, Glaphyra in Deuteronomium, PG 69, 668GD: ,Jesteśmy jednak także jakby pew-

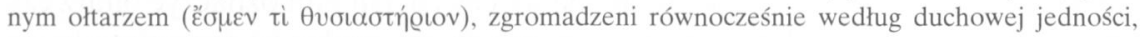
czerpiąc dobrą woń wiary w Chrystusa".

${ }^{69}$ Por. Polycarpus, Epistola ad Philippenses 4, 3; Methodius, Symposion 5, 6 i 8, zob. wyżej przypis 33 i 10.

${ }^{70}$ Por. Constitutiones Apostolorum II 26, 8, SCh 320, 240, ŹMT 42, 44: „Wdowy i sieroty

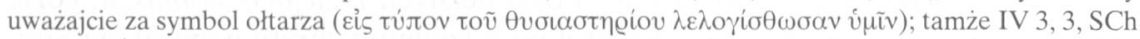
329, 174, ŹMT 42, 98: ,nieletni sierota, słaby starzec, podupadły w chorobę, utrzymujący gromadkę

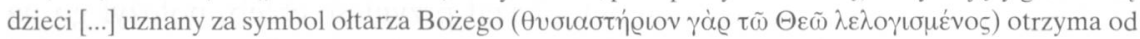
Boga pochwałę"; Joannes Chrysostomus, In Epistola 2 ad Corinthios hom. 20, 3. 


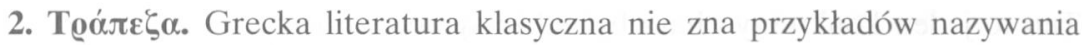

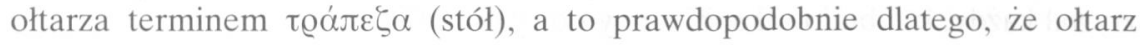
starożytny, choć miał formę stołu, to był czymś stałym, zbudowanym przeważnie z kamienia lub spiżu, stół natomiast był sprzętem ruchomym codziennego użytku, przeważnie z drewna, na którym lub pod którym umieszczano pokarmy, stąd też przenośnie stołem nazywano, podobnie jak dziś, podawane potrawy, jedzenie lub wikt.

Niekiedy terminem tym oznaczano w starożytności stół bankierski, ladę lub kantor, przy którym zbierano podatki lub wymieniano pieniądze, a także platformę-rusztowanie, na którym wystawiano niewolników do sprzedaży, a niekiedy, choć rzadko - płytę z płaskorzeźbą lub napisem (m.in. płytę grobową). Choć te wszystkie znaczenia występują w literaturze patrystycznej, to chrześcijańskie zastosowanie tego terminu na oznaczenie ołtarza wywodzi się przede wszystkim z Biblii. Już w Starym Testamencie, jak zauważyliśmy wyżej, mówiło się o świątynnych ołtarzach w formie stołów z drzewa akacjowego: ołtarzu całopalenia pokrytego miedzianymi blachami (Wj 27, $1-8 ; 38,1-7)$ i ołtarzu kadzenia pokrytym złotymi blachami (Wj 30, 1-10; 37,

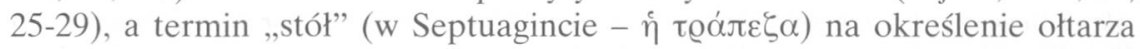
użyty jest wprost tylko dwa razy, przez proroka Ezechiela: „Przy stole moim

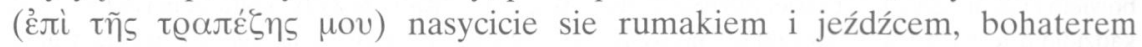
i wszelkim domownikiem” (Ez 39, 20) i Malachiasza: „Oto przynosicie na

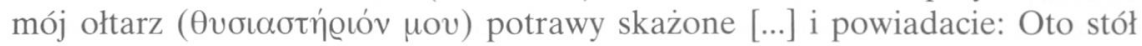

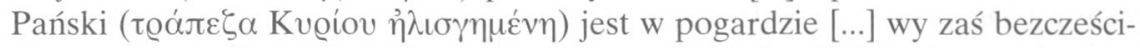

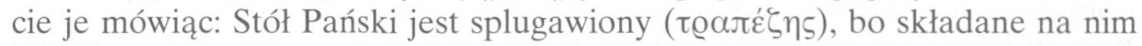
ofiary są miernej wartości” (Mlch 1, 7 i 12). Najwięcej jednak na przyjęcie tej nazwy jako synonimu ołtarza wpłynął Nowy Testament, gdzie w Ewangeliach, zaznaczone jest, iż Chrystus na stole (Mt 26, 20; Łk 22, 14; J 13, 12) ustanowił Eucharystię i złożył pierwszą bezkrwawą ofiarę, a przede wszystkim słowa św. Pawła z Listu do Koryntian: „Nie możecie pić z kielicha Pana i z kielicha

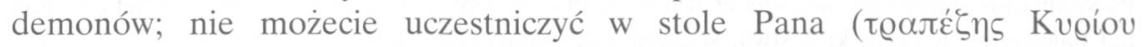

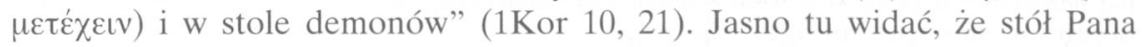
( rzowi demonów.

W późniejszej literaturze patrystycznej autorzy chrześcijańscy posługiwali

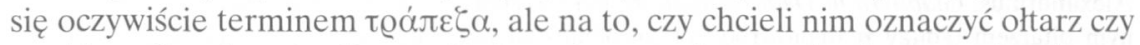
zwykły stół, wskazuje albo znajdująca się przy nim przydawka przymiotnikowa (np. święty, Boży, Pański, mistyczny) lub rzeczownikowa (np. Pana, Boga, Chrystusa), albo kontekst. Użycie tego terminu w tym drugim wypadku - na oznaczenie ołtarza spotykamy już w apokryficznych Dziejach Tomasza, gdzie m.in. czytamy, że Juda Tomasz Apostoł po udzieleniu chrztu generałowi Sifurowi oraz jego rodzinie i dworzanom, ,kazał przynieść chleb, położył go na

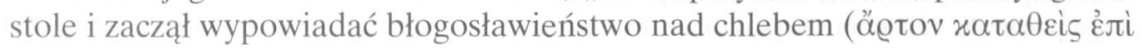




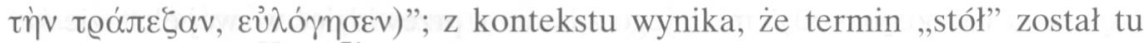
użyty w funkcji ołtarza ${ }^{71}$.

O wiele częściej autorzy wczesnochrześcijańscy na oznaczenie ołtarza używali terminu $\varrho \alpha \dot{\pi} \varepsilon \zeta \alpha$ z dołączoną, przydawką. I tak już na początku III wieku czytamy w Komentarzu do Księgi Przysłów św. Hipolita Rzymskiego († 235), że „święte i czcigodne Jego Ciało i Krew są sprawowane i ofiarowywane na

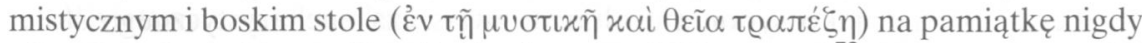
nie wyrażalnej pierwszej boskiej i tajemniczej Wieczerzy"72. Potem w 1. poł. IV wieku tego terminu na oznaczenie ołtarza eucharystycznego używał Cyryl Jerozolimski $(† 386)$ mówiąc do neofitów o „mistycznym i duchowym stole

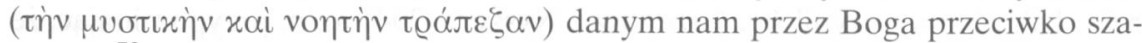
tanom"73, a także historyk Euzebiusz z Cezarei († 339) zaznaczający, że „przyjęliśmy pamiątkę owej Ofiary odprawianej na stole przez symbole (ìेv

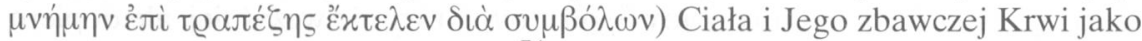
ustanowienia Nowego Przymierza"74.

Stosunkowo często terminem ,stół” oznaczano ołtarz w 2. poł. IV wieku; często czynił to św. Atanazy Aleksandryjski ( $† 373)$, broniąc się m.in. przed oskarżeniami arian, że przez swego Makarego zniszczył kielich i wywrócił stół ołtarz ich kapłana Ischyrasa w czasie sprawowania przez niego Ofiary ${ }^{75}$, lub też skarżąc się, że arianie napadali na kościoły prawowiernych chrześcijan, wyrzucali $\mathrm{z}$ nich meble kościelne wraz z drewnianym stołem-ołtarzem i palili je publicznie przed drzwiami ${ }^{76}$; to beszczeszczenie świątyń i „stołu kościoła

${ }^{71}$ Por. Acta Thomae 133, 1, ed. R.A. Lipsius - M. Bonnet, Acta Apostolorum apocrypha, II 2, Leipzig 1903, 240, 6, tłum. pol. Apokryfy Nowego Testamentu (= ANT), I/2: Apostołowie, Kraków 2007, 674; tamże 49, 2, Lipsius - Bonnet, s. 165, 19, ANT II/1, s. 620: „Apostoł nakazał swemu słudze przygotować łamanie chleba. Ten więc przyniósł stół i przykrywszy go tkaniną lnianą

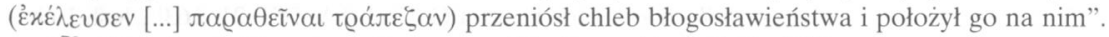

72 Hippolytus, Fragmenta Commentarii in Proverbia, PG 10, 628B.

73 Cyrillus Hierosolymitanus, Catechesis 22, 7, PG 33, 1101B.

74 Eusebius Caesariensis, Demonstratio Evangelica I 10, PG 22, 89D.

75 Athanasius Alexandrinus, Apologia contra arianos 31, PG 25, 300C, tłum. J. Ożóg, PSP 21,

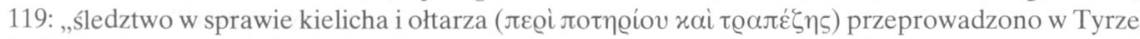
w obecności prefekta i jego oddziału oraz w obecności pogan i żydów"; tamże 83, PG 25, 396D, PSP

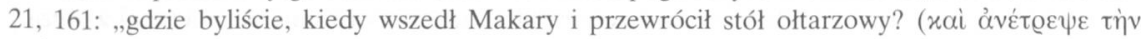

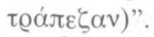

76 Athanasius, Historia arianorum 56, PG 25, 760D: „krzesła, tron, stół ołtarzowy, który był drewniany ( rwane i wyniesione, przed wejściem na wielkim placu spalili"; tenże, Epistola encyclica 3, PG 25, 229A: ,Jedni mieczami lub biczami zostali zabici, inni poranieni i wychłostani, wobec zaś świętego stołu ołtarzowego ( wości, gdy na ofiarę składano ptaki i wychwalano bożki”; przypisywane błędnie Atanazemu Contra

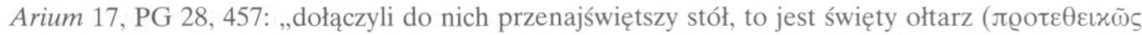

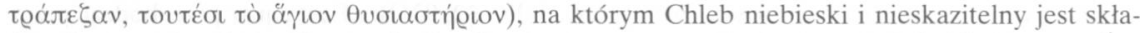
dany”; por. Eutychius, Sermo de Paschate et sacrosancta Eucharistia 8, PG 86, 2401A: „Sw. Atanazy w swojej mowie do niedawno ochrzczonych tak mówił: «Widzicie lewitów, niosących 


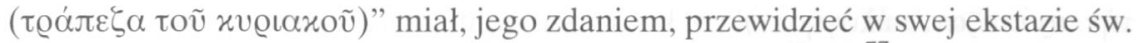
Antoni Pustelnik, co faktycznie po dwóch latach nastąpiło ${ }^{77}$. Czyniły to również cytowane przez niego dokumenty kościelne, związane ze sporami ariań-

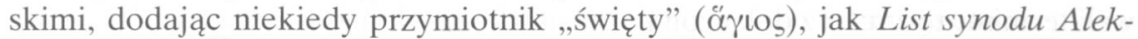
sandryjskiego $^{78}$, List Synodu Jerozolimskiego ${ }^{79}$, List papieza Juliusza ${ }^{80}$, List duchownych Mareoty ${ }^{81}$, czy też List samego Ischyrasa ${ }^{82}$.

Terminu tego, jako synonimu ołtarza, zwłaszcza eucharystycznego stołu, używali także nierzadko Ojcowie Kapadoccy. Czynił to św. Bazyli Wielki $(† 379)$ ubolewając, że innowiercy wywracają i niszczą ołtarze prawowiernych, a w ich miejsce stawiają własne stoły ołtarzowe i na nich składają Ofiarę ${ }^{83}$. Tak również czynił św. Grzegorz z Nyssy († 394) m.in. przypominając, że podobnie jak , dla kultu Bożego jest konsekrowany i poświęcany oraz otrzymuje specjalne błogosławieństwo stół święty i staje się ołtarzem nieskalanym

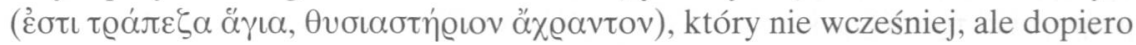

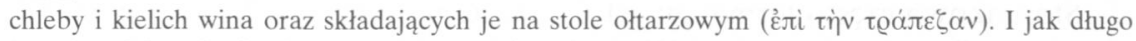
modlitwy i inwokacje nie zostaną nad nimi wypowiedziane, nie są one niczym innym, jak tylko zwykłym chlebem i kielichem»".

77 Por. Athanasius, Vita Antonii 82, PG 26, 957B i 960A, tłum. Z. Brzostowska: Św. Atanazy Aleksandryjski, Żywot świętego Antoniego, Warszawa 1987, 104-105: „Popadłszy w ekstazę [...]

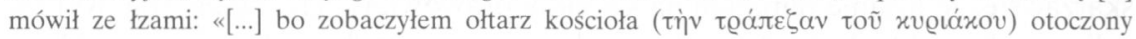
zewsząd mułami, które uderzały weń kopytami» [...]. Po dwóch latach wtargnęli arianie, obrabowali kościoły, siłą wydarli święte naczynia, odciągnęli pogan od warsztatów, zmusili do uczestnic-

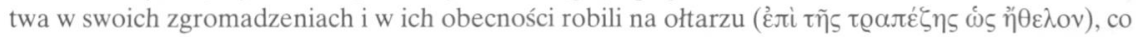
tylko chcieli".

${ }^{78}$ Por. Athanasius, Apologia contra arianos 14 (Epistula concilii Alexandrini), PG 25, 272B, PSP 21, 106: „euzebianie [...] wobec pogan wypytywali o świątynie, o kielich, o stół i rzeczy święte” (

79 Por. tamże 85 (Epistula concilii Hierosolymitani), PG 25, 401A, PSP 21, 163: „Jeśli Ischyrasowi wybuduje się świątynię, będzie się wydawało, że zasługuje na wiarę, kiedy mówi o kielichu

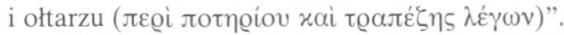

${ }^{80}$ Por. tamże 28 (Epistula Julii Papae), PG 25, 296A, PSP 21, 117: „Ischyras wzywa Boga wszechmogącego na świadka i mówi, że nigdy nie zniszczono żadnego kielicha ani nie przewrócono

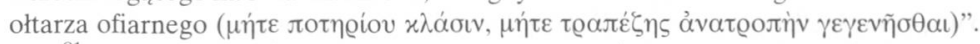

${ }^{81}$ Por. tamże 74 (Epistula clericorum Mareotae), PG 25, 381CD, PSP 21, 154: „Ischyras [...]

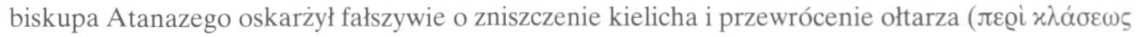

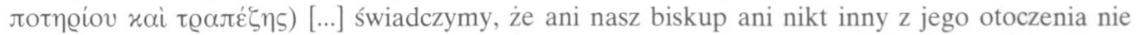

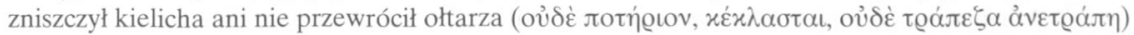
[...] mówimy i oświadczamy, że ani nie zniszczył kielicha, ani nie przewrócił ołtarza ( $\mu \alpha \varrho \tau v \varrho o u ̃ \mu \varepsilon v$

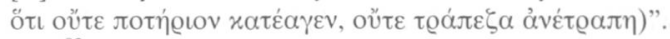

${ }^{82}$ Por. tamże 64 (Epistula Ischyrae), PG 25, 364D, PSP 21, 145: „bo ani kielicha nikt nie

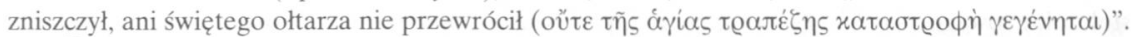

83 Por. Basilius, Epistola 226, 2, PG 32, 845B: „Dlaczego wracając z Dardanii powywracali

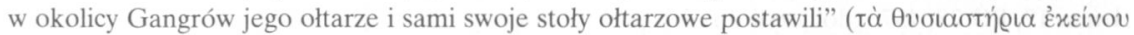

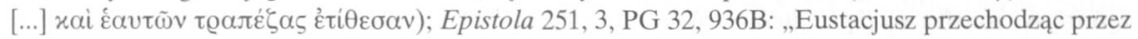
Paflagonię wywracał ołtarze Bazylidesa Paflagończyka i na własnych stołach ołtarzowych składał

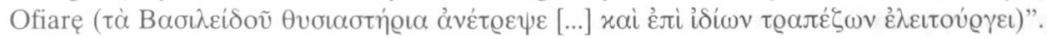


teraz jest obsługiwany przez samych kapłanów, tak i chleb, który na początku jest zwyczajny, ale gdy go uświęci tajemnica staje się i nazywa się Ciałem Chrystusa" ${ }^{84}$. Tak wreszcie czynił i trzeci wielki Kapadocczyk - św. Grzegorz z Nazjanzu ( $† 390)$, który w swoim autobiograficznym poemacie wołał, że „nie pragnie złota, ani barwnych mozaik, ani obrusów na stół mistyczny (ov̉ঠè

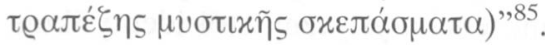

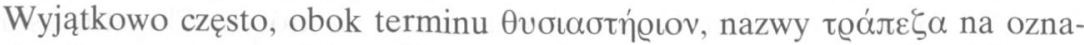
czenie ołtarza używał „doktor Eucharystii” św. Jan Chryzostom († 407); nie-

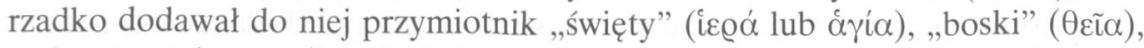

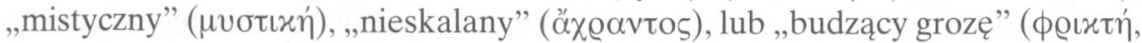

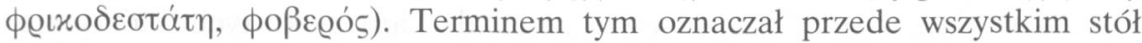
eucharystyczny, ubolewając, że niektórzy zbliżają się „niegodnie do owego świętego i budzącego strach stołu” ${ }^{\prime 26}$, że „przy tym budzącym grozę i mistycznym” oraz „nieskalanym stole” nieodpowiednio się zachowują, bo bez szacunku rozmawiają, nie uświadamiając sobie, że na nim Baranek Boży się ofiaruje, tryska z niego ogień duchowy, a Cherubini i Serafini go uwielbiają i otaczają ${ }^{87}$, że nie można zbliżać się do niego pozostając m.in. z kimś w nieprzyjaźni lub nienawiści (Mt 5,24$)^{88}$, ale by móc zbliżać się do tego budzącego strach stołu godnie, trzeba pozbyć się wszelkiego grzechu i nie-

${ }^{84}$ Gregorius Nyssenus, In baptismum Christi, PG 46, 581C.

85 Gregorius Nazianzenus, Poemata de semetipso. Carmina II sec. I 12, v. 188, PG 37, 1161A, tłum. A.M. Komornicka: Św. Grzegorz z Nazjanzu, Poemat o moim życiu, Poznań 2003, 81; por. Oratio 43, 52, PG 36, 564A, tłum. pol.: Św. Grzegorz z Nazjanzu, Mowy wybrane, Warszawa 1967,

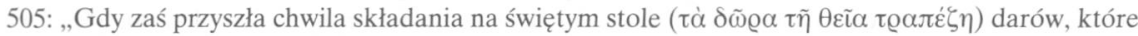
on sam [Bazyli] przyniósł [...] wtedy jego cierpienie stało się widoczne. Zachwiał się, i gdyby ktoś

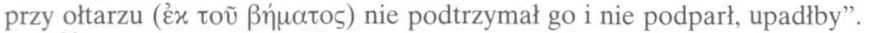

${ }^{86}$ Por. Joannes Chrysostomus, Epistolae ad Olympiadem 17/4, 3c, SCh 13bis, 380: „którzy

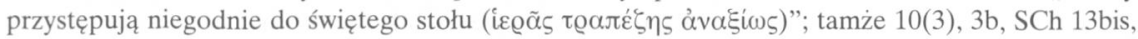
250: „zbliżają się niegodnie do świętych tajemnic uczestnicząc w uczcie owego budzącego strach

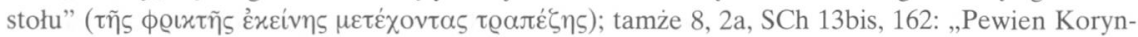
tyjczyk oczyszczony już w świętej kąpieli, dopuszczony został do uczestnictwa przy budzącym

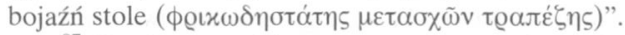

87 Por. Joannes Chrysostomus, De poenitentia hom. 9, 1, PG 49, 345A, tłum. T. Sinko: Św. Jan Złotousty, Dwadzieścia homilij $i$ mów, Kraków 1947, 150: „Mówię do tych, którzy opuszczają

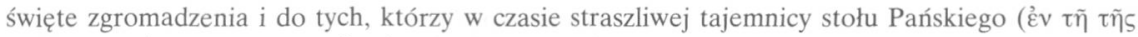

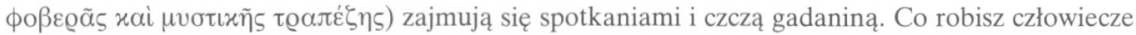

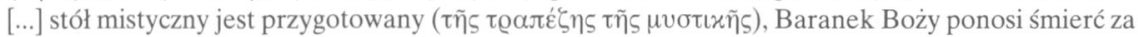
ciebie, kapłan trudzi się dla ciebie, ogień duchowy wybucha z niepokalanego stołu (Jv@ò

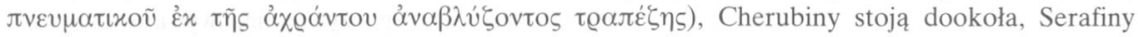
latają [...] a ty nie boisz się, nie wstydzisz się nawet?".

88 In Matthaeum hom. 16, 9, PG 57, 251, tłum. J. Krystyniacki, ŹMT 18, 207: „stół ten nie

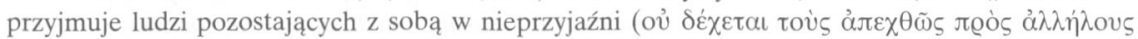

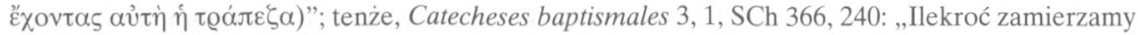
zbliżyć się do świętego stołu, mamy nakaz kochania się wzajemnie i udzielania sobie świętego

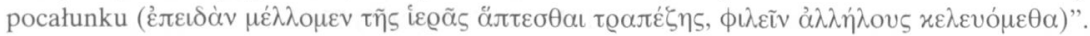


czystości $^{89}$, bo na świętym ołtarzu nie tylko spoczywa Ciało Pańskie, ale na nim stoi również krzyż, który figuruje na wszystkich chrześcijańskich sprzętach i czynnościach ${ }^{90}$; jest to jeden jedyny dostępny dla wszystkich stół, dla ubogich i bogatych, a nawet dla władców odzianych w purpury i diademy, przy którym rozdziela sie Komunię Świętą nie według dostojeństw, lecz według woli i usposobienia ${ }^{91}$. Ten właśnie eucharystyczny stół identyfikuje Jan Chryzostom ze stołem Ostatniej Wieczerzy, na którym Chrystus ustanowił Najświętszy Sakrament, przy którym to "przejmującym strachem stole"

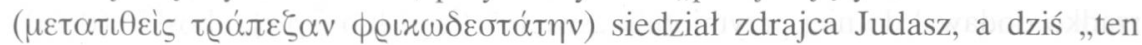

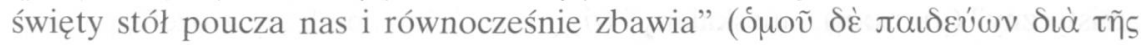

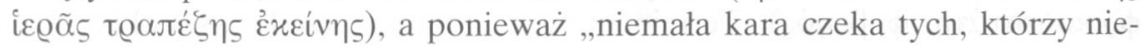
godnie przystępują” do niego, ,winniśmy przystępować z gorliwością do tego

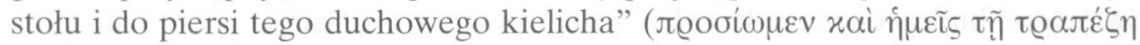

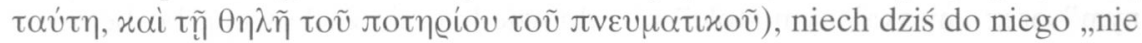
przystępuje żaden Judasz, żaden chciwiec [...] bo ten stół takich nie dopuszcza

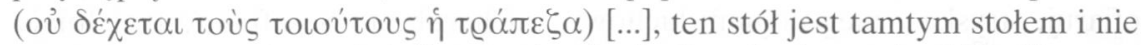

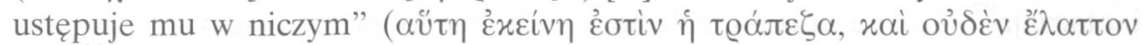
$\check{\varepsilon} \chi \chi \varepsilon \iota)^{92}$. Jan Chryzostom ubolewa, że na ten święty stół, na którym składany jest w ofierze Chrystus, niektórzy chrześcijanie, zgodnie ze starym pogańskim zwyczajem, niekiedy przysięgają, a ołtarz przecież nie dla przysiąg został ustanowiony, ale dla modlitwy i gładzenia grzechów ${ }^{93}$. Innym razem przema-

${ }^{89}$ Por. Joannes Chrysostomus, De poenitentia hom. 6, 5, PG 49, 322: „Zaklinam cię [...] pozbądź się wszelkiego grzechu i dopiero wtedy przystąp do tego budzącego strach stołu (ovitw

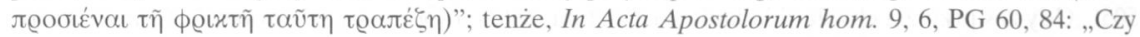

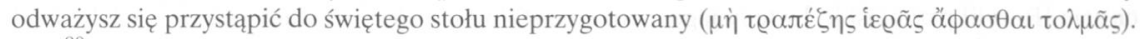

${ }^{90}$ Por. Joannes Chrysostomus, Contra Judaeos hom. 8, 8-9, PG 48, 824-826: ,na zbroi krzyż,

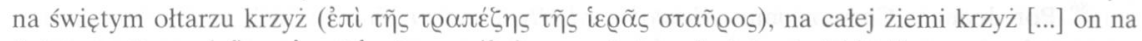

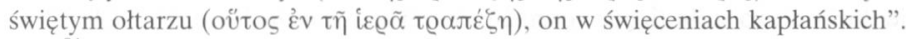

${ }_{91}$ Por. Joannes Chrysostomus, Adversus ebriosos et de resurrectione 3, PG 50, 437, thum. T. Sinko: Św. Jan Złotousty, Dwadzieścia homilij i mów, s. 181-182: „Jeden jest stół i dla bogacza i dla biedaka i choć kto jest bogaty, nie może nic dodać do stołu [...]. Czemu się dziwisz, że dla bogacza

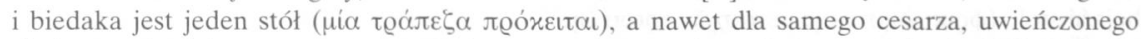
diademem i odzianego w purpurę, któremu powierzona jest władza nad ziemią, i dla żebraka proszącego o jałmużnę jeden stół jest zastawiony. Takie są dary Pańskie: nie według dostojeństw rozdziela Komunię Świętą, ale według woli i usposobienia”.

92 Por. Joannes Chrysostomus, In Matthaeum hom. 82, 1-2 i 5, PG 58, 738-739 i 744, tłum. A. Baron, ŹMT 23, 451, 455, 461-462.

93 Por. Joannes Chrysostomus, De statuis 15, 5, PG 49, 160: „Co czynisz, człowiecze? Przysięgasz na święty stół ( czy na nim składasz na ofiarę swego brata [...]. Nie dlatego ten święty stół On ustanowił, abyśmy na

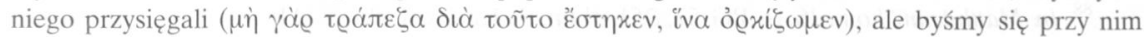
modlili i gładzili swoje grzechy"; zob. Palladius, Dialogus de vita Joannis Chrysostomi 6, PG 47, 22A: „Temu Izydorowi pewna pochodząca z arystokracji wdowa dała tysiąc srebrników przysię-

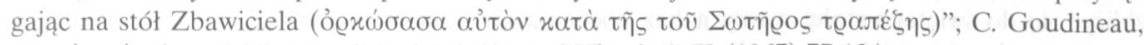

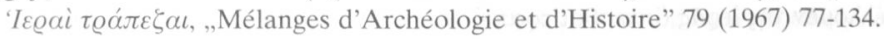


wiając w okresie Bożego Narodzenia identyfikuje ten ołtarzowy stół ze żłóbkiem i obecnym w nim Chrystusem ${ }^{94}$.

Złotousty, choć bez wątpienia chyba najczęściej z greckich Ojców Kościoła nazywał ołtarz ,stołem” ( $₫ \alpha \dot{\tau} \varepsilon \zeta \zeta \alpha$ ), to nie był w tym oryginalny, bo jak widzieliśmy, czynili to zarówno przed nim, jak i po nim i inni autorzy wczesnochrześcijańscy obdarzając go różnymi przydawkami: „święty”, „,boski”, mistyczny”, „nieskalany”, albo jak to po raz pierwszy uczynił św. Paweł (1Kor 10, 21) „stół Pański" ( $\varrho \alpha ́ \pi \varepsilon \zeta \alpha$ Kv@íov) przypominając, że sam Pan na ołtarzu przygotowuje ucztę dla wierzących i Sam się im na pokarm oddaje ${ }^{95}$.

Później podobnie ołtarz nazywali „nienaruszonym” (őovios) ${ }^{96}$ lub „świętym (í@@) stołem" ${ }^{97}$ Synezjusz z Cyreny († 414), który uważał go także za miejsce azylu ${ }^{98}$, „świętym ( $\check{\gamma} \gamma(\alpha)$ stołem” mnich św. Nil z Ancyry ${ }^{99}$, „,́́więtym (į@á) stołem" historycy Kościoła V wieku - Sokrates ${ }^{100}$, Sozomen ${ }^{101}$ i Teodo-

${ }^{94}$ Por. Joannes Chrysostomus, De beato Philogonio 3, PG 48, 753: „Jeżeli z wiarą się do niego zbliżymy, to bez wątpienia zobaczymy go leżącego w żłóbku, tak ten stół wypełniony jest żłóbkiem

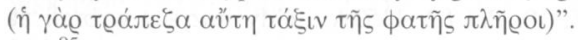

${ }^{95}$ Por. Origenes, Contra Celsum VIII 24, PG 11, 1553A; tłum. S. Kalinkowski: Orygenes, Przeciw Celsusowi, Warszawa 1886, 396: „Paweł wyraźnie stwierdza, że nie można zasiadać rów-

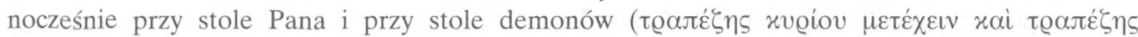
$\delta \alpha \mu o ́ v \omega v)$. Jasno też przedstawiliśmy nasz pogląd, że choćby istniały demony, którym bywają składane ofiary, to nie powinniśmy w nich uczestniczyć, ponieważ wiemy, na czym polega różnica między stołem Pańskim a stołem demonów, w tej sytuacji starajmy się robić wszystko, ażeby zasiadać bez przerwy przy stole Pana".

96 Synesius Cyrenensis, Catastasis I, PG 66, 1573B: „umieszczę przed sobą święte wazy z lustrzaną wodą, będę obejmował święte kolumny, które unoszą nad ziemią nienaruszony stół (

97 Por. tenże, Catastasis II, PG 66, 1569C: „Nie dostawili potem zwykłych i świętych stołów

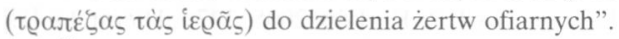

98 Por. tenże, Epistola 58, PG 66, 1400C: „Zbliżył się do stołu szukając ratunku jako miejsca azylu (

99 Por. Nil Ancyranus, Epistolae I 44, PG 79, 104B: „Nie ma już zwykłego chleba i zwykłego

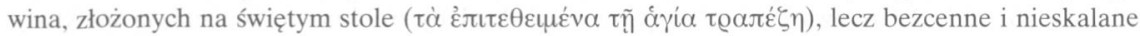
Ciało i Krew Chrystusa".

100 Por. Socrates, HE I 37, PG 67,176B, tłum. S. Kazikowski: Sokrates Scholastyk, Historia Kościoła, Warszawa 1972, 103: „Aleksander [...] wszedłszy do prezbiterium padł na twarz przed

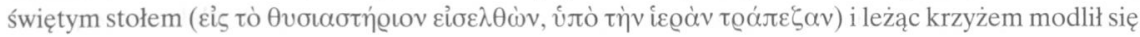
wśród łez".

101 Por. Sozomenus, HE V 20, PG 67, 1280A, tłum. S. Kazikowski: Hermiasz Sozomen, Historia Kościoła, Warszawa 1989, 343: „Cesarz [Julian] [...] kazał spalić kościoły wzniesione dla

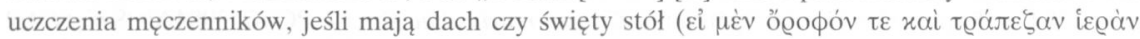

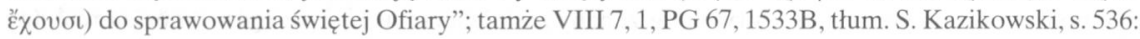
„Eutropiusz [...] przybył do kościoła jako błagalnik szukający pomocy i kiedy tak leżał u stóp

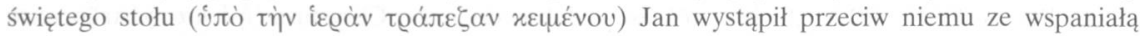
mową”; tamże IX 1, PG 67, 1596A, tłum. S. Kazikowski, s. 582: „Pulcheria [...] ofiarowała i złożyła w kościele konstantynopolskim arcydzieło ze złota i drogocennych kamieni [...] stół święty (íعò̀v

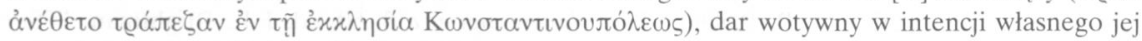
panieństwa i cesarskich rządów brata". 


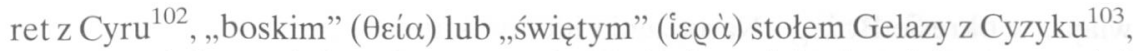

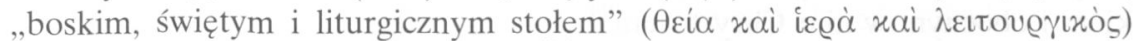
Bazyli - biskup Izauryjskiej Seleucji ${ }^{104}$, „Świętym (iॄ@à) stołem” Pseudo-Dionizy Areopagita ${ }^{105}$, w VI wieku „czcigodnym” ( i $\left.\mu i \alpha\right)^{106}$ lub „świętym” (į@人) $)^{107}$ stołem Ewagriusz Scholastyk, co również przyjmuje późniejsza Kronika Paschalna informując, że ,relikwie św. Tymoteusza, ucznia św. Pawła Apostoła, przeniesione $\mathrm{z}$ wielką czcią do Konstantynopola, zostały złożone

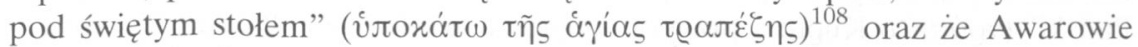
podczas najazdu na Konstantynopol plądrując go ,połamali także święty stół ( Promotii" $" 109$.

Warto tu też dodać, iż zdarzało się, że w literaturze patrystycznej, zwłaszcza tej późniejszej, terminu $๘ \varrho \alpha ́ \tau \varepsilon \zeta \alpha$ jako synonimu ołtarza używano niekiedy także przenośnie, oznaczając nim m.in. grób Chrystusa ${ }^{110}$, samego Chrystusa

102 Por. Theodoretus Cyrensis, HE IV 15, 10, PG 82, 1153A: „Gdy wszyscy wybrali na następcę Antiocha i przyprowadziwszy go zmusili do uklęknięcia przed świętym stołem ( $\pi \alpha \varrho \dot{\alpha}$

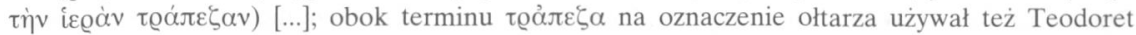
terminu $\beta \omega \mu$ ó , por..HE III 12, 3, PG 82, 1108B.

103 Por. Gelasius Cyzicenus, HE II 31, 6, PG 85, 1317A: „Także tu na boskim stole (غ̇ंi $\tau \tilde{\eta} \varsigma$

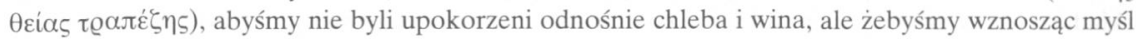
do Boga rozumieli, że dzięki kapłanom ofiarowany jest bezkrwawo złożony na owym świętym stole (

104 Por. Basilius Seleucensis, De vita S. Theclae I, PG 85, 560A: „Za wolą Bożą ukazała mu się

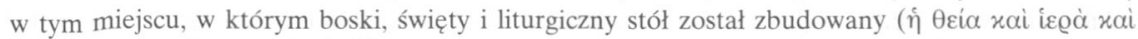

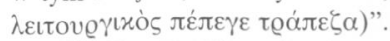

105 Por. Ps-Dionysius Areopagita, Ecclesiastica hierarchia II 2, 4, PG 3, 3950, tłum. M. Dzielska: Pseudo-Dionizy Areopagita, Pisma teologiczne, wyd. 2, Kraków 2005, 147: „Hierarcha [...] rozpoczyna nabożny śpiew świętego hymnu [...], a potem złożywszy pocałunek na świętym stole (

106 Por. Evagrius, HE VI 21, PG 86, 2876C, thum. S. Kazikowski: Ewagriusz Scholastyk, Historia Kościoła, Warszawa 1990, 280: „,[Chosroes] zlecił, by zrobiono także dziękczynny krucy-

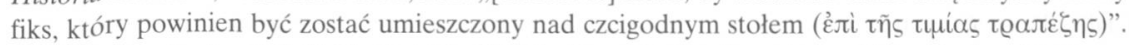

107 Por. tenże, HE V 21, PG 86, 2836A, tłum. S. Kazikowski, s. 250: „kiedy późną nocą [cesarz Maurycy] paląc kadzidło przebywał na modlitwie w sanktuarium kościoła [...] nagle

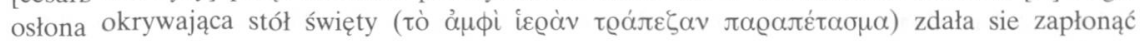
żywym ogniem".

108 Por. Chronicon Paschale 356 (284 Olimpias), PG 82, 733A.

109 Por. tamże 623 (350 Olimpias), PG 92, 1001A.

110 Por. Sophronius Hierosolymitanus, Commentarius liturgicus 2, PG 87, 3984A: „Święty stó1

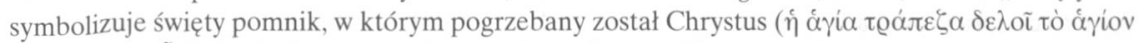

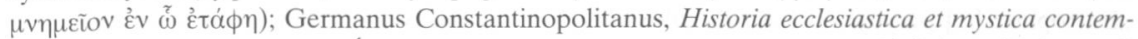

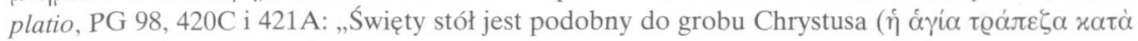

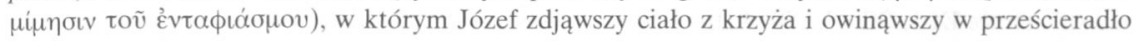

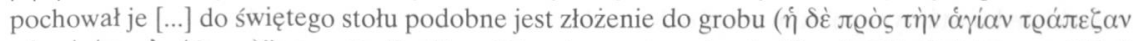

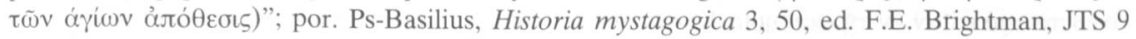
(1908) s. 257, 8 i 287, 14. 
zstępującego z nieba na podobieństwo manny ${ }^{111}$, a nawet łono Najświętszej Maryi Dziewicy noszące Chrystusa ${ }^{112}$.

Wszystkie powyższe greckie nazwy ołtarza chrześcijańskiego mają, jak już zaznaczaliśmy, swoje odpowiedniki łacińskie, najczęściej: altare, altarium, ara lub mensa; na każdą z tych nazw przytoczymy po kilka przykładów.

\section{U ŁACIŃSKICH OJCÓW KOŚCIOŁA}

1. Altare - to najczęstsza ogólna nazwa ołtarza chrześcijańskiego w łacińskiej literaturze patrystycznej. W literaturze klasycznej występowała ona przeważnie w liczbie mnogiej - altaria $^{113}$, chrześcijanie zaś, prawdopodobnie pod wpływem Biblii, adaptowali ją w liczbie pojedynczej - altare, najczęściej na oznaczenie ołtarza, na którym składa się Ofiarę eucharystyczną: w tym znaczeniu używali go wszyscy zachodni Ojcowie Kościoła; z najważniejszych można tu wskazać Tertuliana ${ }^{114}$, który tworząc łacinę chrześcijańską na oznaczenie ołtarza, jak zaznaczaliśmy, używał także innych terminów, zwłaszcza ara $^{115}$; biskupa Kartaginy św. Cypriana, który utrwalił i upowszechnił ideę, że jeden ołtarz jest wyrazem jedności Kościoła ${ }^{116}$; biskupa Mediolanu św. Ambrożego, dla którego „ołtarz jest symbolem ciała, a na ołtarzu spoczywa Ciało Chrystusa”

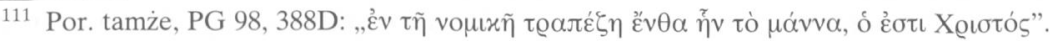

112 Por. Ps-Joannes Damascenus, De immaculato corpore 4, PG 55, 409C: „Słowo Boże,

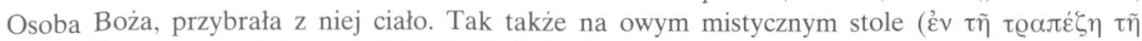
$\mu v \sigma \tau \iota x \tilde{\eta})$ spoczywa nie inaczej, jak w łonie Dziewicy".

113 Por. m.in. Lucretius, De rerum natura VI 752: „fumant altaria donis”; Cicero, De haruspicum responsis 9: „ab altaribus religiosissimis fugatus”; Vergilius, Aeneis VII 211: „numerorum divorum altaribus auget”; Ovidius, Epistulae ex Ponto II 3, 99: „cum faceres altaria pinguia ture”; Velleius Paterculus, Historia Romana II 22, 2: „superfuso [...] altaribus sanguine”; Lucanus, Pharsalia III 404: „structae divis altaribus arae” (tu o najwyższej części ołtarza).

114 Nazwy altare użył Tertulian kilkanaście razy por. G. Claesson, Index Tertullianeus, t. 1, Paris 1974, 92; zob. np. De oratione 5, 3, CCL 1, 260: „Clamant ad Dominum animae martyrum sub altari”; tamże 11, 1, CCL 1, 263: „,ne prius ascendamus ad altare Dei, quam, si quid discordiae vel offensae cum fratribus contraxerimus, resolvamus”; tamże 28, 4, CCL 1, 273: ,agape coronatam cum pompa operum bonorum inter psalmos et hymnos deducere ad Dei altare debemus omnia nobis a Deo impetraturam".

115 Por. wyżej noty 16-18.

116 Por. Cyprianus np. De unitate Ecclesiae 17, CCL 3, 262: „Hostis altaris, adversus sacrificium Christi rebellis [...] constituere audet aliud altare, precem alteram illicitis vocibus facere [...] divina animadversione punitur”; Epistola 1, 2, 1, CCL 3B, 4: „Neque enim apud altare Dei meretur nominari in sacerdotum prece, qui ab altari sacerdotes et ministros voluit avocare"; Epistola 3, 3, 2, CCL 3B, 15: „Sic de Ecclesia receditur, sic altare profanum foris conlocatur, sic contra pacem Christi [...] atque unitatem Dei rebellatur”; Epistola 43, 5, 2, CCL 3B, 205: „aliud altare constitui aut sacerdotium novum fieri praeter unum altare et unum sacerdotium non potest”; Epistola 65, 1, 2, CCL 3C, 427: „quasi post aras diaboli accedere ad altare Dei fas est”; zob. wyżej noty $20-21$. 
lub „ołtarz Chrystusa jest wyobrażeniem Jego Ciała”117; biskupa Hippony św. Augustyna ${ }^{118}$, który uczył, ze „przez świątynię i ołtarz należy rozumieć samego Chrystusa" 119 , o ołtarzu zaś mówił w swych pismach, gdy uczył lub komentował teksty biblijne o wzajemnej ewangelicznej miłości braterskiej, bez której nie można zbliżać się do ołtarza (Mt 5, 23-24) i uczestniczyć w kulcie chrześcijańskim $^{120}$, a Chleb Niebieski należy przyjmować przy ołtarzu z pełną czystością i niewinnością ${ }^{121}$; są bowiem tacy, którzy do tego Bożego i niebieskiego ołtarza zbliżają się nieczyści i niegodni, za co poniosą odpowiedzialnośćc ${ }^{122}$ bo „ołtarz możemy brać również w znaczeniu duchowym, jako wiarę we wnętrzu Bożej świątyni, a której to wiary widzialnym znakiem jest ołtarz"123, oraz kiedy jako duszpasterz uzasadniał za św. Pawłem, że ci, „którzy posługują przy ołtarzu, mają udział w ofiarach ołtarza" (1Kor 9, 13) $)^{124}$, a zwłaszcza kiedy włączając się w spory z donatystami, idąc za myślą św. Cypriana wskazywał na ołtarz, jako symbol jedności chrześcijaństwa, zarzucając im, że w konkurencji budują „altare contra altare”, a dwa ołtarze w jednej miejscowości są już wyrazem schizmy $^{125}$. Biskup Hippony wypowiadał się też na ten temat przenośnie, że

117 Por. Ambrosius np. De sacramentis IV 2, 7, PL 16, 456A: „Veniebas ergo desiderans ad altare quo acciperes sacramentum [...] forma corporis altare est, et Corpus Christi est in altari"; tamże V 2, 8, PL 16, 467A: „Ecclesia videns se ab omnibus mundatam esse peccatis et dignam quae ad altare Christi possit accedere (quid est enim altare nisi forma corporis Christi)", thum. L. Gładyszewski, POK 26, 73 i 80; zob. też Prudentius, wyżej nota 24.

118 Św. Augustyn użył w swoich pismach terminu altare ponad 400 razy (ok. 10 razy o ołtarzu pogańskim, ok. 240 - o ołtarzu kultu żydowskiego i ok. 150 razy o ołtarzu chrześcijańskim), por. Thesaurus Patrum Latinorum. Thesaurus Augustinianus, curante CETEDOC, Lovanii 1989, 41; zob. także V. Saxer, Altare, w: Augustinus-Lexikon, hrsg. C. Mayer, vol. I, Stuttgart 1986, 241-245.

119 Augustinus, Quaestiones evangeliorum I q. 34, PL 35, 1329: „Intelligendum templum et altare ipsum Christum".

${ }_{120}$ Por. Augustinis, De civitate Dei XXI 27; Enchiridion ad Laurentium 79; Contra Faustum XVI 10; De sermone Domini in monte I 10, 26-27.

121 Por. Augustinus, In Joannem tract. 26, 11, 20, CCL 36, 265: „quam multi de altari accipiunt et moriuntur [...] panem caelestem spiritualiter manducate innocentiam ad altare apportate [...] antequam ad altare accedatis, attendite quid dicatis”; Sermo 17, CCL 41, 134: „lota facie ad altare accedamus".

122 Por. Augustinus, Enarrationes in Ps. 25(2), 10, PL 36, 193 lub CCL 38, 147: ,,est et altare coram oculis Dei, quo ingressus est Sacerdos, qui pro nobis se primus obtulit. Est caeleste altare, et non amplectimur illud altare, nisi qui lavat manus in innocentibus. Nam multi altare hoc tangunt indigni et tolerat Deus pati iniuriam ad tempus sacramenta sua [...]. Lava ergo in innocentibus manus tuas et circumda altare Domini, ut audias vocem laudis", zob. thum. pol. PSP 37, 192; Sermo 95, 7, PL 38, 384A: „Altaris sacramenta simul accipiunt boni et mali”.

123 Augustinus, De sermone Domini in monte I 10, 27, CCL 35, 28, PSP 48, 38.

124 Por. Augustinus, De consensu evangelistarum II 73; In Joannem tract. 122, 3; De opere monachorum 10 i 31; Contra adversarium Legis 2, 37.

125 Por. Augustinus, Psalmum contra donatistas (8 razy ,altare contra altare”); Contra Cresconium II 2, PL 43, 468: „qui altare contra altare in eadem civitate erexit, magnum scandalum factum est”; tamże IV 8-9, PL 43, 553: „videmus tamen levatum altare contra altare et ordinatum episcopum contra episcopum [...] erecto altari contra altare, ordinatus est Maiorinus"; In epistolam 
ołtarzem jest m.in. nasze serce - „,czyste serce bez grzechu jest najlepszym ołtarzem”"126. Współczesny i rodak św. Augustyna - Optat z Milewy - walcząc z donatystami również podkreślał, że jeden ołtarz jest symbolem jedności Kościoła, budowanie altare contra altare jest wyrazem schizmy, każde zaś jego zniszczenie jest świętokradztwem, bo każdy ołtarz jest siedzibą ciała i krwi Chrystusa $^{127}$. Sw. Hieronim ${ }^{128}$, który jako egzegeta o ołtarzu (altare) mówił w swoich pismach przede wszystkim przy komentowaniu Pisma Świętego, podkreślając przy tym m.in., że podobnie jak w Izraelu był jeden ołtarz i jedna wiara, tak i w Kościele winien być jeden ołtarz, bo ich wielość jest wyrazem herezji lub schizmy ${ }^{129}$; w swoich zaś listach nie tylko ubolewał, że podczas prowadzonych wojen morduje się nierzadko kapłanów i biskupów, burzy się kościoły, a nawet bezcześci się ołtarze ${ }^{130}$, ale i przypominał, że do ołtarza

Joannis ad Parthos 3, PL 35, 199: „Si in unitate sumus, quid faciunt in hac civitate duo altaria”; Contra litteras Petiliani I 26, PL 43, 257: ,aperte se separant, aperte altare contra altare erigunt”; De baptismo II 7, PL 43, 130: „Quare contra orbem terrarum altare erexistis”; tamże VI 37, 72, PL 43, 220: ,illa est enim consuetudo, quae si sacrilegos ad altare Christi sine baptismi purgatione admittebat”; Contra donatistas 21, 33, CSEL 53, 135, 24: „omnes ad unum altare accedebant et eadem sacramenta communicabant”; De civitate Dei XXII 10, 20, CCL 48, 828: „nec ibi erigimus altaria in quibus sacrificemus martyribus”; Sermo 46, CCL 41, 949: „Mali sodales fecerunt sibi suas mensas erexerunt altaria contra altare"; Contra epistolam Parmeniani II 5, 10, PL 43, 56: „qui contra Ecclesiam Dei toto orbe diffusam altare sui schismatis erexerunt".

${ }^{126}$ Por. Augustinus, De civitate Dei X 3, 2, CCL 47, 275: „cum ad illum sursum est, eius est altare cor nostrum”; De natura et gratia 41 i 71, PL 44, 267 i 282: „Per hoc enim quotidianum spirituale quodammodo incensum, quod ante Deum in altare cordis, quod sursum habere admonemur, infertur [...]" i ,,altare optimum [...] cor mundum sine peccato".

127 Por. Optatus Milevitanus, Contra Donatistas VI 1, 1-2, SCh 413, 160: „Quid enim tam sacrilegum quam altaria Dei, in quibus et vos aliquando obtulistis, frangere, radere, removere, in quibus et vota populi et membra Christi portata sunt, quo Deus Omnipotens invocatus sit, quo postulatus descenderit Spiritus Sanctus, unde a multis et pignus salutis aeternae et tutela fidei et spes resurrectionis accepta est [...]. Quid est enim altare nisi sedes et corporis et sanguinis Christi?"; zob. tamże I 15, 3; 19, 3 i 4; II 8, 1; 18, 1; 20, 5; 21, 6; III 12, 2; VI 1, 1-10; 3, 6; 5, 1.

128 Św. Hieronim użył w swoich pismach terminu altare prawie 400 razy (dokładnie -395 razy), por. Thesaurus Patrum Latinorum. Thesaurus S. Hieronymi, curante CETEDOC, Lovanii 1990, 26.

129 Por. Hieronymus, In Isaiam V 19, v. 19-20, PL 24, 191: „Cum turba Judaeorum aedificavit templum et altare et propheticam Christi cassa implere temeritate conatus est. Ita autem unum altare dicitur, quomodo una fides et unum baptisma et una Ecclesia"; In Amos I v. 14-15, PL 25, 1022: ,non unum altare, quod habet Ecclesia, sed altaria haereticorum plurima. Tot enim habent altaria, quot schismata”; In Ezechielem XIII w. 18, PL 24, 424: „Postquam prophetae monstravit altare [...] et quattuor altaris cornua [...] et docet eum quomodo altaris opere perfecto altare debeat expiari et consecrari”; Epistola 64, 9, CSEL 54, 596, 5: „Legimus in Exodo, tabernaculum, mensam, altare, columnas [...]”; Epistola 130, 2, CSEL 56, 176, 22: ,in qua Sancta Sanctorum et thymiatis altare describitur".

130 Por. Hieronymus, Epistola 60, 16, PL 22, 600: „his bellis fuere ludibrio. Capti episcopi, interfecti presbyteri et diversorum officia clericorum. Subversae ecclesiae, ad altaria Christi stabulati equi, martyrum effossae reliquiae”; Epistola 114, 2, PL 22, 934: „et altaris Christi ministerio descrivere”; Epistola 108, 13, CSEL 55, 322, 13: „Quid narrem Silo, in quo altare dirutum hodieque monstratur". 
Chrystusowego, wysadzanego niekiedy drogimi kamieniami, należy zbliżać się z czystym sumieniem ${ }^{131}$, że zgodnie z nauką św. Pawła (1Kor 9, 13) duchowni obsługujący ołtarz mają prawo do korzystania z jego ofiar ${ }^{132}$. Św. Leon Wielki papież, który w swoich kazaniach używał nazwy altare nie tylko przenośnie, mówiąc o altare cordis lub altare crucis $^{133}$, ale i przy komentowaniu Biblii, gdy mówił o „nowym ołtarzu” eucharystycznym, który zastąpił dawne prawo i ołtarze żydowskie ${ }^{134}$ i uzmysławia krzyż Chrystusa ${ }^{135}$; ołtarz zaś żydowski nazwał $\operatorname{ara}^{136}$. Pod koniec epoki patrystycznej św. Grzegorz Wielki papież również, choć rzadziej ${ }^{137}$, używał terminu altare na oznaczenie ołtarza, zarówno w odniesieniu do ołtarzy żydowskich Starego Testamentu ${ }^{138}$, jak i chrześcijańskich wznoszonych w bazylikach lub kościołach ${ }^{139}$, z nierzadkim przypominaniem, że do ołtarza należy przystępować godnie i z czystym sercem ${ }^{140}$,

131 Por. Hieronymus, Epistola 125, 17, CSEL 56, 136, 20: „ut adolescentiam tuam nulla sorde commacules, ut altare Christi quasi de thalamo virgo procedas"; Epistola 52, 10, CSEL 54, 431, 15 : „gemmis altare distinguitur et ministrorum Christi nulla electio".

132 Por. Hieronymus, Epistola 66, 8, CSEL 54, 657, 2: „Dignus est operarius mercede sua: qui altari ministrant, de altari participantur”; Epistola 147, 10, CSEL 56, 327, 12: „Noverat te omnis Italia, universi ante altare Christi stare ingemiscebant".

133 Por. Leo Magnus, Sermo 51(64), 3, SCh 74, 87: „Quod umquam sacrificium sacratius fuit, quam quod verus Pontifex altari crucis per immolationem suae carnis imposuit”; Sermo 95(4), 1, SCh 200, 266: „Et quid tam sacerdotale quam vovere Domino conscientiam puram et immaculatas pietatis hostias de altari cordis offerre";

134 Por. Leo Magnus, Sermo 46(59), 5, SCh 74, 60: „ut veterum victimarum cessante mysterio, nova hostia, novo imponeretur altari, et crux Christi non templi esset ara, sed mundi"; Sermo 41(54), 5, SCh 74, 35: „Hoc mane vobis templum et altaria diruit, legem et prophetas ademit, regnum et sacerdotium sustulit".

135 Por. Leo Magnus, Sermo 42(55), 3, SCh 74, 38: „Crux ergo Christi sacramentum veri et praenuntiati habet altaris, ubi per hostiam salutarem naturae humanae celebraretur oblatio".

136 Por. wyżej nota 134.

137 Sw. Grzegorz Wielki użył w swoich pismach terminu altare blisko 150 razy (dokładnie 146 razy), por. Thesaurus Patrum Latinorum. Thesaurus S. Gregorii Magni, curante CETEDOC, Lovanii 1986, 20.

138 Por Gregorius Magnus, In I Regum V 148, CCL 144, 509: „Unde et in tabernaculo foederis duo altaria fieri a Domino iussa sunt: adolendis scilicet thymiamatibus unum, alterum comburendae carnis”; In Hiezechielem II hom. 10, 20, CCL 142, 395: „Unde et in tabernaculo per legem duo altaria fieri iubentur".

139 Por. Gregorius Magnus, Epistolae VI 50, CCL 140, 423: „, basilicam in honorem beati Petri et Pauli apostolorum necnon Laurentii atque Pancratii martyrum construxisse atque illic tredecim altaria collocasse”; Epistolae XI 56, 11, CCL 140A, 961: „Aqua benedicta fiat, in eisdem fanis aspargatur et altaria construantur".

${ }^{140}$ Por. Gregorius Magnus, Epistolae I 42, CCL 140, 55: „quia nullus [presbyter] debet ad ministerium altaris accedere, nisi cuius castitas ante susceptum ministerium [...]"; Epistolae IV 20, 22, CCL 140, 238: „nec usque ad rescriptum nostrum ad cultum vos sacri altaris accedere”; Epistolae VII 5, 43, CCL 140, 449: „is qui mitti voluit ante se per altaris calculum purgatum vidit”; Epistolae III 7, 96, CCL 140, 15: „,nec sacris administrare vel communionem capere sit dignus altaribus". 
oraz że ci, którzy ołtarzowi służą, mają prawo żyć z jego ofiar ${ }^{141}$. Stosunkowo często używał też tego terminu, zwłaszcza w swych komentarzach biblijnych, przenośnie, mówiąc m.in, że ołtarzem jest „,cor iusti” ${ }^{142}$, „,cor electi auditoris" ${ }^{\prime 143}$, ,mens bene viventium"144, ,anima iusti” lub ,altare boni operis"145, czy też „conpunctio cordis” ${ }^{146}$. Uważany wreszcie za ostatniego Ojca Kościoła Zachodniego św. Izydor z Sewilli w swoich Etymologiach wyjaśnia znaczenie dwóch terminów - ara i altare, którymi oznacza się ołtarz, bez przypisywania już któremukolwiek pejoratywnej treści. Zaznacza, że odnośnie etymologii pierwszego $\mathrm{z}$ nich $\mathrm{w}$ jego czasach panowały przynajmniej trzy opinie: jedni wyprowadzali tę nazwę od palonych na ołtarzu ofiar, inni od błagalnych modlitw nazywanych w Grecji ả@ás, a jeszcze inni od wysokości, z czym on się nie zgadza. Od wysokości natomiast wyprowadza nazwę altare, dodając iż oznaczano nią też tylko górną część ołtarza" ${ }^{147}$.

2. Altarium - nazwa pochodna od altare, nieznana autorom klasycznym, ukształtowana w łacinie ludowej i akceptowana przez autorów wczesnochrześcijańskich. Na jej w ogóle stosunkowo rzadkie występowanie w ich pismach, głównie na terenie Galii i Afryki, duży wpływ miał starołaciński przekład

141 Por. Gregorius Magnus, In I Regum IV 212, CCL 144, 413: „dicens, qui evangelium adnuntiat de evangelio vivat, qui altario serviunt, de altario vivant; hanc quippe legem regni Dominus loquebatur".

142 Por. Gregorius Magnus, In Hiezechielem II hom. 10, 19, CCL 142, 19: „Recte igitur horum cor altare Dei dicitur, ubi ex moerore compunctionis ignis ardet et caro consumitur"; In I Regum III 173, CCL 144, 294: „Quid est enim altare Domini nisi cor iusti [...]. Qui pro amore supernae patriae bona agit [...] profecto altare aedificat, super quo quotidiani desiderii hostias incendat”.

143 Por. Gregorius Magnus, In I Regum VI 73, CCL 144, 591-592: „Immolationis quidem victima [...] in altari cognoscitur. Quid enim est cor electi auditoris nisi altare Dei. Quando ergo bona doctor loquitur ore et ostendit opere [...] victima in altari".

144 Por. Gregorius Magnus, In Hiezechielem II hom. 10, 19, CCL 142, 394: „Et quid est altare Dei nisi mens bene viventium".

145 Por. Gregorius Magnus, Regula pastoralis III 9, 57-48 i 106-108, SCh 382, 298 i 302: ,recte ad Ezechielem esse in altari Dei fossa perhibetur, ut in ea videlicet superposita holocausta serventur. Si enim in altari fossa non esset, omne quod in eo sacrificium reperiret, superveniens aura dispergeret. Quid vero accipimus altare Dei, nisi animam iusti, quae quot bona egerit, tot super se ante eius oculos sacrificia imponit. Quid autem est altaris fos sa, nisi bonorum patientia [...]. Fossa ergo in altari fiat, ne superpositum sacrificium aura dispergat [...] hoc solum sacrificium Deus accipit, quod ante eius oculos in altari boni operis flamma caritatis incendit".

146 Por. Gregorius Magnus, In I Regum V 148, CCL 144, 509: „potest altaris nomine conpunctio cordis intelligi. Quando enim per verbum doctoris conpunctio cordis erigitur, nimirum altare Domino aedificatur [...]. Primum altare foris erat, secundum intra sancta sanctorum. Altare ergo primum conpunctio timoris est, altare secundum conpunctio amoris [...]. Altare ergo primum doctor aedificat, quando culpas exponit [...]. Merito etiam altare conpunctio dicitur, quia incensat".

147 Por. Isidorus Hispalensis, Etymologiae XV 4, 13-15, BAC 434, 240: „Aram quidam vocatam dixerunt, quod ibi incensae victimae ardeant. Alii aras dicunt a precationibus, id est quas Graeci ả@ás dicunt [...] alii volunt ab altitudine aras, sed male. Altare autem ab altitudine constat esse nominatum, quasi alta ara"; zob. wyżej nota 1. 
znanej sentencji św. Pawła: „Qui altario deserviunt, de altario participantur” (1Kor 9,13). Najwcześniej nazwa altarium poświadczona jest w pismach przypisywanych św. Cyprianowi z Kartaginy ${ }^{148}$, potem pojawia się u św. Ambrożego $^{149}$ i u Sulpicjusza Sewera ${ }^{150}$, stosunkowo często (po ok. 12 razy), ale głównie przez cytowanie lub interpretowanie powyższej sentencji paulińskiej, występuje u św. Augustyna ${ }^{151}$ i św. Hieronima ${ }^{152}$, później u Arnobiusza Młodszego $^{153}$, a szczególnie w pismach autorów galijskich, jak np. w liście biskupa Lupusa i Eufroniusza ${ }^{154}$, oraz Salwiana $\mathrm{z}$ Marsylii ${ }^{155}$, u Paulina z Noli, który obok przeważnie używanego terminu altare, nazywał też niekiedy ołtarz - altarium ${ }^{156}$, u żyjącego pod koniec V wieku galijskiego biskupa

148 Por. Ps-Cyprianus, De singularitate clericorum 38, CSEL 3/3, 213: ,altariis placere debent, qui altariis vivunt, et talis convenit sinceritatis cura"; Ad Vigilium de Judaica incredulitate 9, CSEL 3/3,130: ,cum te exemptum de iustorum grege atque adsumptum sibi de inopinato constituit altario sacerdotem".

149 Por. Ambrosius, In Epistolam I ad Corinthios 9, 13, PL 17, 230C: „In sacrariis legem gentilium significat in altario vero Judaeorum".

150 Por. Sulpicius Severus, Dialogi II 2, 1, CSEL 1, 181: „quo quidem die - mira dicturus sum cum iam altarium, sicut est solemne benediceret".

151 Por. Augustinus, De consensu evangelistarum II 30, 73, CSEL 43, 179: „qui altario deserviunt, de altario conpartiuntur. Sic et Dominus ordinavit"; ten sam cytat zob. De opere monachorum 9, 10, CSEL 41, 546, 13; Sermo Domini in monte II 54, CCL 35, 145; Speculum 31, CSEL 12, 215, 25; Sermo 2, 54, ed. C. Iambot, w: Stromata Patristica et Mediaevalia, I, Roma 1950, 1170; Sermo 218B, ed. G. Morin, w: Miscellanea Agostiniana, I, Roma 1930, 450: „hodie celebramus; quod quidem et aliis diebus nec ab altario, cui assistimus, nec ab ore nostro"; Epistola 54, 4, CSEL 34/2, 162, 11: ,auctoritate antistitis debet quisque ab altario removeri ad agendam poenitentiam”; Sermo 58, w: „Ecclesia Orans” 1 (1984) 123, 86: „sic vivamus, ut ab altario tuo non separemur”.

152 Por. Hieronymus, Adversus Jovinianum II 22, PL 23, 318 :"Qui altario deserviunt, de altario participantur"; ten sam cytat zob. Commentarius in Titum, PL 26, 602, 21 i 635, 7; Tractatus de Psalmo 83, CCL 78, 392: „Sub altario Dei erant, qui pro Christo in martirio fuerant immolatae; victima enim Domini Salvatoris in caelis esse sub altario merebatur"; Commentarioli in psalmos 119, CCL 72, 13: ,,similem deprecatur, ut detur ei carbo de altario Dei, qui in eius labiis peccatorum solitudinem"; Dialogus contra Luciferianos 5, PL 23, 159B: ,indicta in populorum oratione, altario reconciliat [...] a cunctis hominibus conculcandus, super altarium reponis"; Epistola 14, 8, CSEL 54, 55, 9: ,clerici oves pascunt, ego pascor. Illi de altario vivunt, mihi quasi infructuosae arbori securis ponitur”; Epistola 70, 9, PL 22, 663D: „Heri catechumenus, hodie pontifex, heri in amphitheatro, hodie in ecclesia, vespere in circo, mane in altario"; Epistola 52, 11, PL 22, 536: "Qui altario deserviunt, vinum et sinceram non bibant".

153 Por. Arnobius Junior, Commentarius in Psalmum 67, PL 53, 419D: „Laedere enim student sacerdotum consilia qui hoc loco tauri nominantur apti altario inter vaccas".

${ }^{154}$ Por. Lupi et Euphronii Epistola II, PL 58, 66C: „ut qui non vult in clericatu generari, non constituat in altario coniugatos".

155 Por. Salvianus, De gubernatione Dei I 21, SCh 220, 120: „Cur ante altaria supplicamus?”; tamże VI 38, SCh 220, 386-388: „Spernitur Dei templum, ut curratur ad theatrum. Ecclesia vacuatur, circus impletur. Christum in altario dimittimus”; tamże VII 74, SCh 220, 484: „quos ita solos puros fuisse arbitror in altario".

${ }^{156}$ Por. Paulinus Nolanus, Epistola 32, 8, PL 61, 334C: „,ne semel condita in altario, non semper ad manum [...] subiciatur altaribus, hic apertos titulus indicabit”. 
Werana $^{157}$, w Sacramentarium Gallicanum ${ }^{158}$, u św. Grzegorza Wielkiego ${ }^{159}$ oraz bardzo często w dokumentach galijskich synodów VI wieku ${ }^{160}$, a szczególnie w pismach św. Grzegorza z Tours ${ }^{161}$. Trzeba tu też zauważyć, że altarium w łacińskiej literaturze patrystycznej nie zawsze oznaczało sam ołtarz, ale także przestrzeń wokół niego, jak to np. spotykamy u wspomnianego Grzegorza z Tours, gdy opowiadał, że altarium bazyliki św. Marcina posiada 32 okna $^{162}$, a wcześniej u św. Hieronima ${ }^{163}$ czy św. Paulina z Noli, gdy pisał do Seweryna o pewnej inskrypcji in altario, a kilka linijek dalej sam ołtarz nazywał altare (altaria) $)^{164}$.

3. Ara - nazwa oznaczająca ołtarz w pogańskiej literaturze klasycznej, przez chrześcijańskich autorów odnoszona początkowo, jak widzieliśmy, prawie wyłącznie do ołtarzy pogańskich lub żydowskich, później gdy pogaństwo i judaizm przestały już być groźne, semantycznie i treściowo coraz częściej traktowana była jako synonim terminu altare. Jeśli chodzi o wzajemny semantyczny stosunek tych nazw do siebie, to ara ma bardziej charakter domowy i rodzinny, odnosi się raczej do ołtarzy domowych i rodzinnych, na których składano ofiary bóstwom domowym i rodzinnym (penates), w przeciwieństwie do altaria, które były raczej ołtarzami publicznymi i państwowymi. Na używanie zaś tej nazwy przez Ojców Kościoła w odniesieniu do ołtarzy chrześcijańskich wpłynął także starołaciński przedhieronimowy przekład Biblii, w której terminem ara oznaczano ołtarz, jak np. ,,vidi animas occisorum sub ara Dei claman-

157 Por. Sancti Verani Sententia, PL 72, 703A: „Incongruum mihi videtur de coniugali toro aliquem consurgentem altariorum saepta penetrare".

158 Por. Sacramentarium Gallicanum (Missa in S. Mariae solemnitate), PL 72, 475A: „Altario tuo, Domine, proposita munera Spiritus Sanctus benignus adsumat"; Exorcismus, PL 72, 572A: „Benedictio palmae et olivae super altario".

159 Por. Gregorius Magnus, In I Regum IV 212, PL 144, 4484: „qui evangelium adnuntiat, de evangelio vivat, qui altario serviunt, de altario vivant".

${ }^{160}$ Por. Concilium Aurelianense (a. 511), can. 14 i 15, CCL 148A, 9: ,ut de his, quae in altario oblatione fidei conferentur [...] de his tamen, quae in altario accesserint"; Concilium Epaonense (a. 517), can. 29, CCL 148A, 31: ,constituto tempore admettendis ad altarium observatio relaxetur"; Concilium Vasense (a. 529) subscriptiones CCL 148A, 80: „recitemus ante altarium Domini”; Concilium Aurelianense (a. 541) can. 13, CCL 148A,135: „,de quolibet corpore venientes adque altario mancipatus"; Concilium Arelatense can. 1, CCL 148A, 171: „ut oblatae, quae in sancto offeruntur altario"; Concilium Turonense (a. 567) can. 23, CCL 148A, 191: „repellant nec participare sancto altario permittant"; Concilium Autissiodorense (a. 561-605) can. 8, CCL 148A, 266: „non licet in altario in sacrificio divino mellita [...] offerre".

${ }^{161}$ Por. Gregorius Turonensis, Opera, ed. B. Krusch - Levison - Holzman, MGH Script. Merov. I, Hannoverae 1937, 934 (sub voce altarium).

162 Por. tenże, Historia Francorum II 14, MGH Script. Merov. I 82: „fenestras in altario triginta duas".

163 Por. wyżej nota 152.

164 Por. wyżej nota 156. 
tium et dicentium" (Ap 6,9). Na większą skalę zaczęło się to w 2. poł. IV wieku, choć wcześniej spotykaliśmy to już u Tertuliana ${ }^{165}$, a później często u Prudencjusza na oznaczenie całego lub części ołtarza, czy też przestrzeni wokół niego $^{166}$. Czynił to m.in. św. Ambroży ${ }^{167}$, biskup św. Maksym z Turynu w kazaniu o św. Cyprianie, powołując się na wspomniany wyżej starołaciński przekład Biblii $^{168}$, galijski biskup Sydoniusz Apolinary ${ }^{169}$, Fulgencjusz z Ruspe ${ }^{170}$; stosunkowo często używał tej nazwy największy łaciński wczesnochrześcijański egzegeta - św. Hieronim ze Strydonu ${ }^{171}$, który w swoich komentarzach biblijnych posługiwał się tym terminem najczęściej w tradycyjnym sensie - w odniesieniu do ołtarzy pogańskich (m.in. do ołtarza na ateńskim Areopagu: Dz 17, $23)^{172}$ lub żydowskich ${ }^{173}$ czy heretyckich $^{174}$; innym razem nazwy altaria i arae uważał za synonimy ${ }^{175}$, albo też używał tej drugiej przenośnie mówiąc m.in.

165 Por. wyżej nota 17.

166 Por. wyżej nota 24.

167 Por. Ambrosius, De virginibus I 11, 65, PL 16, 218A: „nostra puella dudum nobilis saeculo, nunc nobilior Deo, cum urgueretur ad nuptias a parentibus et propinquis ad sacrosanctum altare confugit [...]. Stabat ad aram Dei pudoris hostia, victima castitatis".

168 Por. Maximus Taurinensis, Sermo 78, PL 57, 689-690A: „Videte autem quem iidem [martyres] locum apud homines mereantur, qui apud Deum locum sub altare meruerunt. Dicit enim Sacra Scriptura: «Vidi subtus aram Dei animas occisorum propter Verbum Dei et propter testimonium quod habebant et clamaverunt» (Ap 6, 9). Sub ara, inquit, Dei animas occisorum. Quid reverentius, quid honorabilius dici potest, quam sub illa ara requiescere, in qua Deo sacrificium celebratur, in qua offeruntur hostiae, in qua Dominus et sacerdos [...]. Recte ergo sub ara martyres collocantur, quia super aram Christus imponitur".

169 Por. Sidonius Apollinaris, Carmina XVI 124, PL 58, 721A: „Seu te conspicuis gradibus venerabilis arae cancionatarum".

170 Por. Fulgentius, Sermo 56, PL 65, 925D: „Sub ara Joannes de quo mater sterilis erubescebat, et super aram positus Christus, de quo mater virgo gaudebat"; zob. Codex Theodosianus 9, 45, 4: ,,ara salutis”.

171 Św. Hieronim użył tej nazwy w różnych znaczeniach prawie 100 razy (dokładnie $=99$ ), por. Thesaurus Patrum Latinorum. Thesaurus S. Hieronymi, curante CETEDOC, Turnhout 1990, 37-38. 172 Por. Hieronymus, Epistola 70, 2, CSEL 54, 702, 3: „pro Christo causam agens etiam inscriptionem fortuitam arae retorquet in argumentum fidei"; Epistola 14, 15, CSEL 54, 51, 2: „si quis duobus digitalis thura comprehensa in bustum arae iaciat aut haustum patera fundat"; In Ezechielem II 6, 526, CCL 75, 69: ,interfecti vestri ceciderint in medio ararum idolorum vestrorum”; Epistola 72, 3, CSEL 55, 10, 20: „in omnibus urbibus Juda extruxerint aras ad cremandum thus"; In Oseam I 4, 142, CCL 76, 41: „quot homines habuit Israel, tot aras exstruxit daemonibus".

173 Por. Hieronymus, In Hieremiam III 70, 204, 19, CCL 74, 161: ,in pectore cordis eorum et in cornibus altarium sive ararum eorum".

174 Por. Hieronymus, In Ezechielem II 6, 388, CCL 75, 65: ,interpretantur ecclesiae et excelsa superbiae eorum et arae perversorum dogmatum; In Amos III 7, 256, CCL 76, 320: ,nec dimittit ut dissipentur arae quae risu et subsanatione sunt dignae”; In Oseam II 10, 29, CCL 76, 92: „ut pro uno altari, quod verum est, plures errori sui aras exstruxerunt".

175 Por. Hieronymus, In Hieremiam III 70, 4, CCL 74, 162: „exaratum sive insculptum est in cornibus altarium vel ararum eorum, ut opera sacrilegii in aeternum”; zob. wyżej nota 172 i niżej nota 176 . 
o „ara consecrationis"176. I on używając nazwę ara znajdował się pod wpływem starołacińskiego tłumaczenia Biblii i przy jej komentowaniu zachowywał występujące w niej wyrażenia, a wśród nich także termin $\operatorname{ara}^{177}$. Nigdy jednak nie użył go na oznaczenie ołtarza eucharystycznego.

Równie często tej uroczystej nazwy ara używał św. Augustyn ${ }^{178}$, znajdując się także zarówno pod wpływem starołacińskich przekładów Bibli ${ }^{179}$, jak i retoryki. Świadom był, że z nastaniem chrześcijaństwa, zmieniało się także słownictwo, że pogańska terminologia zastępowana była inną, że wielowiekowa nazwa ołtarza ara ustąpiła innej - altare: „in Christo cederet ara altari” ${ }^{180}$. Mimo to, choć nazwę ara odnosił nadal tradycyjnie do ołtarza pogańskiego ${ }^{181}$, a idąc za starołacińskimi przekładami Biblii - także do ołtarzy w niej wspominanych ${ }^{182}$,

176 Por. Hieronymus, In Isaiam VI 15, 2, 15, CCL 73, 256: „more torrentis periturus sit in quo habebant quasi aram consecrationis suae".

177 Por. Hieronymus, In PS. 83, 4, CCL 78, 392: „sub quo [altari] errant animae iustorum. Sic enim dicit: «Vidi sub ara Domini animas occisorum propter verbum Domini et testimonium Jesu» (Ap 6, 9); Contra Vigilantium 6, PL 23, 344: „A As enim vel in sinu Abrahae, vel in loco refrigerii, vel subter aram Dei animas apostolorum et martyrum consedisse”; In Oseam II 8, 245-256: „ „Ephraim fecit altaria ad peccandum. Factae sunt ei arae in delictum» [...] in quibus peccatis peccata coniungeret; quae altaria, id est arae vertentur in delictum"; In Hiezechielem II 6, 355 i 526, CCL 75, 64 i 69: „«dispergam ossa vestra circa aras vestras» [...] interfecti vestri in medio ararum idolorum vestrorum”; In Hieremiam III 71, 1, CCL 74, 162: „, Recordati fuerint filii eorum ararum suarum et lucorum ignorum".

178 W pismach św. Augustyna termin ara występuje 105 razy, por. Thesaurus Patrum Latinorum. Thesaurus Augustinianus, curante CETEDOC, 56 i 59.

179 Por. Augustinus, Contra Gaudentium I 27, 30, CSEL 53, 228: „Joanne dicente: vidi, inquit, animae occisorum sub ara Dei exclamantium [...]. Ad haec responsio: si sub ara Christi martyres esse velletis, non vos ipsos incendendo sacrificium diabolo faceretis"; Enarrationes in Ps. 78, 14, 3, CCL 39, 1107: „Scriptum est in Apocalypsi, sub ara Dei martyres ad Deum clamare et dicere [...] inde est ille sub ara Dei martyrum clamor”; Epistola 36, 24, CSEL 34, 53, 20: „ubi martyres clamant sub ara Dei”; Contra Gaudentium I 27, 30, CSEL 53, 228, 24: „quid enim animae martyrum sub ara Dei dicunt”.

180 Augustinus, Epistola 36, 24, CSEL 34, 44: ,ut in Christo cederet ara altari, gladius jejunio, precibus ignis".

${ }^{181}$ Por. Augustinus, De unico baptismo 4, 6, CSEL 52, 7, 14: „Apostolus, cum eorum fana circumiens ara quaedam inter aras inventa”; Contra Crescentium I 30, 35, CSEL 52, 355, 9: „cum et Apostolum videamus etiam in ara gentilium, a quibus idola celebrantur, Dei nomen inventum confirmasse”; Enarratio in Ps. 94, 6, 22, CCL 39, 1335: ,daemonibus templa fabricata, daemonibus arae constructae, daemonibus sacerdotes”; Sermo 273, 3, 3, PL 38, 1249: „tamquam diis templa aedificantur [...] tamquam diis arae construerentur, tamquam diis sacerdotes ordinarentur"; De civitate Dei IV 18, 19, CCL 47, 113: „Quid diversae aedes, diversae arae, diversa sacra”; In Genesin q. 116, CCL 33, 42: „Non ergo sicut idolatrae solent aras ante lapides constiere et tamquam diis libare lapidibus”; Contra Faustum XX 3, CSEL 25, 537, 15: „Item pagani aris, delubris, simulacris, victimis atque incenso Deum colendum putant”; Epistola 47, 3, CSEL 34, 132, 8: ,scimus ire fumum ex aris omnibus et incensis daemoniorum".

182 Por. Augustinus, De Genesi ad litteram XII 2, 5, PL 34, 455: „ut Esaiae sedens Deus et in conspectu eius Seraphim, et ara unde carbo adsumptus prophetae labia mundavit" (Is 6, 1-7); Sermo 299E, w: Miscellanea Agostiniana, ed. G. Morin, I, Roma 1930, 557, 7: ,ductus est [Isaac] gaudens a gaudente, ligatus est, arae inpositus”; Enarrationes in Ps. 109, 17, 50, CCL 40, 1617: „Numquid erunt 
to jednak oznaczał nią zarówno ołtarz chrześcijański w ogóle ${ }^{183}$, jak i konkretny ołtarz św. Szczepana ${ }^{184}$. Dosyć często używał też tej nazwy przenośnie, mówiąc

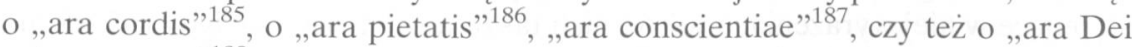
anima nostra" ${ }^{188}$. Nigdy jednak, podobnie jak św. Hieronim, terminem tym, kojarzącym sie zawsze z pogaństwem, nie nazwał wprost ołtarza eucharystycznego. O wiele rzadziej nazwy ara używał w swych pismach papież Grzegorz Wielki ${ }^{189}$, a jeżeli się nią posługiwał, to przeważnie w znaczeniu przenośnym, mówiąc często (8 razy) o „,ara cordis"190 , o ,ara amoris”191, o „ara laudis”"192, o ,ara crucis" ${ }^{193}$, czy też o „,ara orationis” ${ }^{194}$. Zdarzało się jednak, że terminem

illae hostiae, victimae oblatae a patriarchis, arae sanguinis"; Enarrationes in Ps. 50, 23, 7, CCL 38, 615: „Quando totum pecus imponebatur arae igne consumendum, holocaustum dicebatur"; Quaestiones in Genesin 110, 35, CCL 33, 40: „Quid est quod non dixit: et fac ibi aram mihi, qui adparui tibi, sed Deus dicit: fac ibi aram Deo qui adparuit tibi”; zob. też Leo Magnus, wyżej nota 134.

183 Por. Augustinus, Enarrationes in Ps. 94, 6, 36, CCL 39, 1335: „Forte hoc facimus modo, imponimus in ara sacrificium, quando Deum laudamus”; tamże 134, 11, 26, CCL 40, 1946: „forte non invenires in grege tuo placitum taurum et in capris hircum arae Domini dignum"; tamże 140,5, 17, CCL 40, 2029: „oratio ergo pure directa de corde fideli tamquam de ara sancta surgit incensum”; tamże 49,15, 11, CCL 38, 588: „quare aries ille ambulat [...] et in ara mea non ponitur”.

184 Por. Augustinus, Sermo 318, 1, PL 38, 1438, 23: „Nos enim in isto loco non aram fecimus Stephano, sed de reliquiis Stephani aram Deo. Grata sunt Deo huiusmodi altaria”.

185 Por. Augustinus, De civitate Dei X 3, 23, CCL 47, 275: „,ei sacrificam hostiam humilitatis et laudis in ara cordis igne fervidam caritatis".

186 Por. Augustinus, Sermo 305A, w: Miscellanea Agostiniana, I, s. 64, 18: ,et hoc sacrificium tamquam de ara pietatis suavissime flagrat Domino".

187 Por. Augustinus, Enarrationes in Ps. 134, 11, 40, CCL 40, 1946: „corde laudas, corde benedicis, corde in aram conscientiae victimas sacras imponis"; tamże 49, 21, 8, CSEL 38, 591: „ad me redeam, in me inveniam laudis immolationem; sit ara tua conscientia tua”.

188 Por. Augustinus, Enarrationes in Ps. 94, 6, 34, CCL 39, 1335: „, si ergo nos sumus templum Dei, ara Dei anima nostra”.

189 Nazwa ara występuje w autentycznych pismach św. Grzegorza Wielkiego 21 razy, por. Thesaurus Patrum Latinorum. Thesaurus S. Gregorii Magni, curante CETEDOC s. 569.

190 Por. Gregorius Magnus, Moralia in Job XVI 42, 53, 26, CCL 143A, 829: „Sic nos cum in ara cordis holocaustum Deo offerimus”; tamże I 36, 54, 118, CCL 143, 56: ,ante Dei oculos innocentiae victima in ara cordis immolatur"; tamże VIII 47, 79, 68, CCL 143, 444: „hoc ad honorem intimi iudicis in ara cordis immolemus”; In Evangelia hom. 5, 3, PL 76, 1094B: „quando per hoc Deo immolat in ara cordis anima semetipsam mactat”; tamże 10,6, PL 76, 1113B: „si cogitations carnis per sancta orationum studia in ara cordis incendimus”; In Ezechielem hom. II 9, 5, 176, CCL 142, 360: „in quibus Omnipotenti Deo orationis sacrificium in ara sui cordis incendat"; Moralia in Job XXV 7, 16, 132, CCL 143B, 1241: ,et vitam reprobam per immutationis gladium mactat in ara se sui cordis imposuit”.

191 Por. Gregorius Magnus, Moralia in Job I 35, 49, 17, CCL 143, 51: „igitur dare est totam mentem igne compunctionis incendere ut in ara amoris cor ardeat".

192 Por. Gregorius Magnus, In Evangelia hom. 5, 3, PL 76, 1094B: „intra memetipsum tamen invenio quod in ara tuae laudis impono".

193 Por. Gregorius Magnus, In I Regum I 10, 281, CCL 144, 61: „,qui nobis exempla humilitatis vivendo dedit, se Deo Patri in ara crucis oblationem et hostiam tradidit".

194 Por. Gregorius Magnus, Moralia in Job IX 55, 84, 76, CCL 143, 516: „nil terrenum secum, nil lubricum in ara suae orationis imponit". 
tym oznaczał też ołtarz wspominany w Biblii ${ }^{195}$, zniszczony przez św. Benedykta pogański ołtarz Apollina ${ }^{196}$, a także ołtarz chrześcijański, na którym składamy nasze modlitwy i dobre uczynki, jako ofiarę przebłagania ${ }^{197}$. Nazwę te znał także zamykający łacińską epokę patrystyczną - św. Izydor z Sewilli, który, jak wspominaliśmy wyżej, wyprowadzał nawet potrójną jej etymologię ${ }^{198}$. Warto tu też na koniec dodać, że nazwę ara spotykamy także w dwóch starożytnych inskrypcjach hiszpańskich: wyrażenie ,,ara sancta Domini” figuruje na fragmencie ołtarza poświęconej w 630 r. bazyliki hiszpańskiej ${ }^{199}$, a słowa: „Aram in medio altare sacrans" w pewnym hiszpańskim kościelnym napisie dedykacyjnym z 622 r., w którym ara oznacza ołtarz, a altare przestrzeń wokół niego ${ }^{200}$; ponadto wyrażeniem ,ara salutis” oznaczony jest ołtarz chrześcijański w Kodeksie Teodozjańskim ${ }^{201}$, a słowa „super aram crucis” spotykamy nawet w Sakramentarzu Mozarabskim ${ }^{202}$. Z powyższych uwag wynika, że stara łacińska nazwa ołtarza - ara, mimo iż przesiąknięta była wielowiekową treścią pogańską, znajdywała powoli, choć bardzo ostrożnie, zastosowanie w różnoraki sposób także w literaturze wczesnochrześcijańskiej.

4. Mensa - nazwa będąca odpowiednikiem greckiej $\tau \varrho a ́ \pi \varepsilon \zeta \alpha$, również znana była w łacińskiej literaturze patrystycznej na oznaczenie ołtarza, głównie eucharystycznego, choć rzadziej od niej używana. I w tym wypadku jej głównym uzasadnieniem były słowa św. Pawła: „non potestis mensae Domini participes esse et mensae daemonium" (1Kor 10, 21). Pojawia się ona już w przypisywanym św. Cyprianowi traktacie De aleatoribus, gdzie jest mowa o „mensa dominica” - ,stole Pańskim, przy którym Chrystus zasiada, aniołowie spoglądają, a męczennicy są obecni”"203, oraz w Rufinowym łacińskim przekła-

195 Por. Gregorius Magnus, In Ezechielem hom. I 6, 15, 282, CCL 142, 75: „Quid est quod Isaac ad immolandum ducitur et ligna portat area superimponitur et vivit"; Moralia in Job XXVII 10, 17 , 38, CCL 143B, 1342: ,post paululum ligatur et non loquitur; arae superponitur et non reluctatur”.

196 Por. Gregorius Magnus, Dialogi II 8, 11, 104-105, SCh 260, 168: „Ibi itaque vir Dei perveniens, contrivit idolum subvertit aram, succidit lucos, atque in ipso templo Apollinis oraculum beati Martini, ubi vero ara eiusdem Apollinis fuit”; tamże II 37, 4, 28, SCh 260, 244: „Sepultus est vero in oratorio beati Baptistae Joannis, quod destructa ara Apollinis ipse construxit"; zob. też In I Regum 6, 33, 750, CCL 144, 569: „quia velut contempto divino altari ad aras daemonum responsa percipiunt".

197 Por. Gregorius Magnus, In Evangelia hom. 37, 7, PL 76, 1278D: „Mittamus ad hunc legationem lacrimas nostras, mittamus misericordiae opera, mactemus in ara eius hostias placationis".

198 Por. wyżej nota 147.

199 Por. E. Hübner, Inscriptiones latinae Hispaniae Christianae nr 100.

200 Por. tamże nota 363.

201 Por. Codex Theodosianus 9, 45, 4, ed. G.F. Hänel, Bonnae 1842, 966.

202 Por. Liber Mozarabicus sacramentorum, ed. M. Férotin, Paris 1912, 1448.

203 Por. Ps-Cyprianus, De aleatoribus 11, CSEL 3/3, 103: „Esto potius non aleator, sed Christianus, pecuniam suam adsidente Christo spectantibus angelis [...] super mensam dominicam sparge", thum. A. Bober, VoxP 3 (1983) z. 4, 243. 
dzie Recognitiones Pseudo-Klemensa Rzymskiego, gdzie Faustynian prosi św. Piotra, by go umieścił w ,spichlerzu Pańskim i uczynił uczestnikiem Bożego stołu” (mensae divinae participem) ${ }^{204}$. Potem ołtarz nazywał „mensa Dei” św. Piotr Chryzolog, który zachęcał, by zwłaszcza w okresie Wielkanocy nie powstrzymywać się od niego ${ }^{205}$, wyrażeniami „mensa mystica” i „mensa venerabilis" - św. Ambroży z Mediolanu zaznaczając, że do tego „mistycznego i czcigodnego stołu” najlepiej jest przygotować się przez post ${ }^{206}$, a wyrażeniem „mensa caelestis” - św. Paulin z Noli przypominając, że pod tym „niebiańskim stołem" kryją się prochy apostolskie ${ }^{207}$.

Stosunkowo często nazwą mensa, głównie na oznaczenie ołtarza eucharystycznego, posługiwał się św. Augustyn ${ }^{208}$, używając Pawłowego wyrażenia „mensa Domini”209, lub jego pochodnych - „mensa dominica”210, „mensa

204 Por. Ps-Clemens Romanus, Recognitiones X 72, PG 1, 1454A: „Tunc Faustinianus accedens ad pedes Petri dixit [...] reponas me in horreo Dominico, faciens me mensae divinae participem”.

205 Por. Petrus Chrysologus, Sermo 10, PL 52, 218B: „Obsecro et obtestor, fratres carissimi, per Dominum nostrum, ut in hoc vigiletis omnes, quatenus ut his diebus nullus a Dei mensa, nullus a regeneratione divina relinquatur extorris".

206 Por. Ambrosius, De Elia et ieiunio 10, 33, PL 14, 708BC: „Mystica quoque mensa ieiunio comparatur: illa mensa, de qua dicit David: «Parasti in conspectu meo mensam adversus eos qui tribulant me». Mensa ista famis acquiritur pretio: et poculum illud inebrians sobrietate, caelestium sacramentorum siti quaeritur [...]. Ergo si ad mensam illam venerabilem ieiunia sancta nos perducunt: si hac fame illa quae sunt aeterna mereamur".

207 Por. Paulinus Nolanus, Carmen 27, 401-404, CSEL 30, 280: „Spectant de superis altaria tuta fenestris (sub quibus intus habent sanctorum corpora sedem) namque et apostolici cineres sub caelite mensa) depositi placitum Christo spirantis odorem".

${ }^{208}$ Nazwa mensa w autentycznych pismach św. Augustyna występuje w różnych znaczeniach 352 razy, por. Thesaurus Patrum Latinorum. Thesaurus Augustinianus, curante CETEDOC, 402; zob. V. Saxer, Altare, w: Augustinus-Lexikon, I, Stuttgart 1986, 244.

${ }^{209}$ Por. Augustinus, De fide et operibus 6, 9, CSEL 41, 45, 10: „qualis vita debeat esse christiani, ut cum se ipsos probaverint, tunc de mensa Domini manducent"; Enarrationes in Ps. 144, 9, 13, CCL 40, 2094: „,ille avidissimus epulator Joannes apostolus, cui non sufficiebat ipsa mensa Domini, nisi discumberet super pectus Domini”; Sermo 229A, ed. G. Morin, w: Miscellanea Agostiniana, I, 462, 9: „quod videtis in mensa Domini, quantum pertinet ad ipsarum rerum speciem”; Sermo 229, ed. G. Morin, tamże, s. 29, 22: „, hoc quod videtis, carissimi, in mensa Domini panis est et vinum”; Contra litteras Petiliani II 47, 110, CSEL 52, 34, 25: „non dicunt ista nisi qui de mensa Domini vitam sumunt sicut Petrus”; In Joannem tract. 9, 9, 3, CCL 36, 95: „Mensa enim Domini est et non oportet ministrum fraudare convivas”; tamże 84, 1, 35, CCL 36, 537: „qualia de Domini mensa pariter acceperunt”; Epistola 36, 24, CSEL 34/2, 54, 1: ,et tunc in Domini mensa panes propositionis poni solere et nunc se de agni immaculati".

${ }^{210}$ Por. Augustinus, In Joannem tract. 84, 2, 16, CCL 36, 537: ,hactenus talia exhibuerunt, qualia de mensa dominica perceperunt”; tamże 26, 15, 36, CCL 36, 267: „,alicubi certis intervallis dierum in dominica mensa praeparatur et de dominica mensa sumitur"; Sermo 272, PL 33, 1247, 9 : „estis corpus Christi et membra, mysterium vestrum in mensa dominica positum est”; Sermo 46, CCL 41, 947: „,ergo multi sodales ingrati mensae dominicae exierunt foras”; Sermo 90, PL 38, 561, 48: „Omnes qui acceditis in mensam dominicam, quae hic est, nolo esse cum multis separandis”; Sermo 132, PL 38, I 735: „qui autem uxores nondum habetis et tamen ad mensam dominicam iam acceditis et carnem Christi manducatis"; Sermo 229A, ed. G. Morin, Miscellanea Agostiniana, I, 
Christi” "211, „mensa potentis”212, „mensa magna”"213, lub w ogóle „mensa”214 albo „mensa Dei” 215 przypominając, że do tego „stołu” należy się zawsze zbliżać przygotowanym, bez grzechu i z czystym sercem, bo przyjmuje się z niego prawdziwe Ciało i Krew Chrystusa lub inne święte sakramenty. Niekiedy, choć rzadko, używał też tej nazwy przenośnie, gdy mówił o „futura mensa” mając na myśli pośmiertną nagrodę wieczną ${ }^{216}$ lub o osobistym ołtarzu chrześcijanina ${ }^{217}$. Nazwę tę, jako „mensa Cypriani”, odniósł także do znanego sobie i wiernym Kartaginy kamiennego pomnika wzniesionego na miejscu jego męczeństwa i śmierci, zaznaczając, że „na tym miejscu wzniesiono Bogu stół (mensa), który nazywa się stołem Cypriana nie dlatego, żeby kiedykolwiek tam Cyprian ucztował, lecz dlatego, że tam został złożony w ofierze, i że przez samą swoją ofiarę przygotował ten stół nie po to, żeby karmić innych czy siebie, lecz żeby na nim składała się ofiara Bogu, któremu on sam również został złożony w ofierze; stół ten, który jest stołem Boga, nazywa się również stołem Cypriana"218.

463, 2: „immo Christum per apostolum de sacramento mensae dominicae accipitis”; De octo Dulcitii quaestionibus I 14, 365, CCL 44, 269: „disciplina ecclesiastica emendare non possumus aut a mensa dominica separare”; Adversus Judaeos 61, 1, PL 42, 63: „ut nulla facta separatione mensae dominicae ad Christi sacrificium pertinente"; Contra epistulam Parmeniani III 2, 7, CSEL 51, 103, 21: „non solum cibum mensae vestrae sumitis, sed etiam mensae dominicae communicatis”; De peccatorum meritis I 24, 34, CSEL 60, 33, 21: „tenent praeter baptismum et participationem mensae dominicae non solum ad regni Dei”; Enarrationes in Ps. 33, 3, 71, CCL 38, 405: „Matris Ecclesiae pio lacte nutriendum et ad escam mensae dominicae idoneum faciendum".

211 Por. Augustinus, In Joannem tract. 62, 1, 7, CCL 36, 483: „Itane hoc meruit panis Christi, ut post illud intraret in eius discipulum satanas"; Sermo 112A, ed. G. Morin, Miscellanea Agostiniana, I, 260, 5: „ut admitteretur ad mensam, in qua Christus pascitur occisus"; Sermo 164, PL 38, 900, 28 : „sed communicares cum illo Christi mensam”.

212 Por. Augustinus, In Joannem tract. 47, 2, 26-27, CCL 36, 404-405: „Mensa potentis quae sit, nostis; ibi est corpus et sanguis Christi, qui accedit ad talem mensam, praeparet alia"; tamże 84, 1 , 16, CCL 36, 537: „nam quae mensa est potentis, nisi unde sumitur corpus et sanguis eius”.

213 Por. Augustinus, Sermo 329, PL 38, 1455, 8: „«Ad mensam magnam sedisti» (1J 3, 16) [...] quoniam talia te oportet praeparare; mensa magna est, ubi epulae sunt ipse Dominus mensae"; Sermo 31, CCL 41, 20: „quae est magna mensa, nisi unde accipimus corpus Christi et sanguinem”.

214 Por. Augustinus, Sermo 132, PL 38, 735, 4: „Christus cotidie pascit, mensa ipsius est illa in medio constituta”; Sermo 229, ed. G. Morin, Miscellanea Agostiniana, I, 30, 28: , ad calicem Domini venistis et ibi vos estis in mensa et ibi vos estis in calice".

215 Por. Augustinus, Enarrationes in Ps. 136, 16, 30, CCL 40, 1974: „quomodo non fit iniuria mensae Dei, si quod dextrum est, sinistrum feceris".

216 Por. Augustinus, Sermo 179, 5, PL 38, 969, 5: „quantum in illa sua futura mensa daturus”.

217 Por. Augustinus, Sermo 272, PL 38, 1248, 11: „mysterium pacis et unitatis nostrae in sua mensa consecravit”; Adnotationes in Job 36, CSEL 28/2, 590, 10: „et descendit mensa tua plena pinguedine sacramentum corporis et sanguinis eius”; Sermo 138, 7, PL 38, 767, 19: ,quia de mensa tua vivunt et mensae tuae sacramenta tractant".

218 Por. Augustinus, Sermo 310, 2, PL 38, 1413: ,quicunque Carthaginem nostis, in eodem loco mensa Deo constructa est; et tamen mensa dicitur Cypriani, non quia ibi est umquam Cyprianus epulatus, sed quia ibi est immolatus, et quia ipsa immolatione sua paravit hanc mensam, non in qua pascat sive pascatur, sed in qua sacrificium Deo, cui et ipse oblatus est, offeratur. Sed ut mensa illa, 
O połowę rzadziej od Augustyna nazwy mensa w odniesieniu do ołtarza, używał św. Hieronim ${ }^{219}$. Jako egzegeta o stole (mensa) pisał głównie wtedy, gdy była o nim mowa w komentowanym fragmencie Biblii rozumiejąc go tylko niekiedy jako ołtarz, zwłaszcza żydowski. Mimo iż znał słowa św. Pawła: „Non potestis mensae Domini communicare et mensae daemoniorum" (1Kor 10, $21)^{220}$ mówiące o stole eucharystycznym, to jednak bardzo rzadko w tym znaczeniu używał tego terminu, jak np. gdy ostrzegał, że kapłani po zawinionej polucji „nie mogą zbliżać się do stołu kapłańskiego” - „ad sacerdotalem mensam accedere", czyli stołu eucharystycznego ${ }^{221}$. W innych wypadkach, choć mówił o „mensa Domini” ${ }^{222}$ lub o „mensa dominica”223, miał na myśli ołtarz w ogóle, a najczęściej żydowski. Również w pozostałych wypadkach przez ten termin rozumiał przeważnie biblijny ołtarz żydowski, gdy mówił o „mensa thymiamatis" ${ }^{224}$, „mensa propositionis" ${ }^{225}$, „mensa Dei”226, czy tylko „mensa”227. Jeszcze rzadziej niż Hieronim terminem mensa posługiwał się papież św. Grzegorz Wielki ${ }^{228}$. Czynił to najczęściej w swoim Komentarzu do Ezechiela, a zwłaszcza w jego IX homilii komentującej wiersze 40, 59-43 tego proroka, gdzie jest mowa o przyszłej świątyni, w której portykach miały stać stoły ofiarne ${ }^{229}$. Nawet, gdy używał wyrażeń „,mensa Domini”,230 , „mensa

quae Dei est, etiam Cypriani vocetur, haec causa est”, thum. A. Bober, Antologia patrystyczna, Kraków 1965, 259; Sermo 8, CCL 41, 388: „sanctus cuius mensa est ista Cyprianus fuit aliquando”. 219 Św. Hieronim w swoich pismach użył nazwy mensa 188 razy, por. Thesaurus Patrum Latinorum. Thesaurus S. Hieronymi, curante CETEDOC, 283.

220 Por. Hieronymus, Epistola 55, 4, CSEL 54, 494, 16.

221 Por. Hieronymus, Epistola 64, 2, CSEL 54, 590, 2: „si quis e sacerdotibus semine fluxerit, ad sacerdotalem mensam prohibetur accedere".

222 Por. Hieronymus, In Malachiam 1, 330, CCL 76A, 911: „vos autem contaminatis illud in eo quod dicitis, mensa Domini polluta est”; In Ezechielem XI 39, 2059, CCL 75, 544: „tunc scito mensam Domini praeparatam, ut ponant gloriam suam"; In Malachiam 1, 392, CCL 76A, 913: „Mensam quoque Domini contaminatam ad Sacras Scripturas referunt”.

223 Por. Hieronymus, In Naum 1, 10, 318, CCL 76A, 536: „et convivium eorum atque mysteria, quia et ipsi mensam dominicam habere se dicunt".

224 Por. Hieronymus, In Ezechielem XII 41, 1150, CCL 75, 601: „quomodo altare in quo ignis succendendus erat, mensa videlicet thymiamatis, nihil ab igne patiatur".

225 Por. Hieronymus, In Oseam 1, 9, 2, 187, CCL 76, 22: „ex auro purissimo et mensam propositionis aurem".

226 Por. Hieronymus, In Malachiam 1, 7, 232, CCL 76A, 909: „,sed opera peccatorum despiciunt mensam Dei".

227 Por. Hieronymus, In Malachiam 1, 365, CCL 76A, 912: „qui autem arbitrantur non altare, sed mensam debere intellegi, in qua panes ponebantur”; Epistola 22, 4, CSEL 54, 157, 6: „cum aquatius bibimus calix frangitur, mensa subvertitur".

228 Grzegorz wielki użył w swych pismach nazwy mensa 138 razy, por. Thesaurus Patrum Latinorum. Thesaurus S. Gregorii Magni, curante CETEDOC, 208.

229 Por. CCL 142, 355-377.

230 Por. Gregorius Magnus, In Hiezechielem II hom. 9, 502, CCL 142, 370: „Tunc autem mensa Domini ex quadris lapidibus extructa habebit intus labium [...]"; In I Regum 4, 88, 1688, CCL 144, 339: „Cum in mensa Domini panes abundant”; Moralia in Job XX 2, 4, 41, CCL 143A, 
Dei”"231, czy „mensa Ecclesiae”232, to rozumiał przez nie przeważnie biblijne ołtarze żydowskie lub stoły ofiarne, a nigdy stołu eucharystycznego, który wolał nazywać inaczej; raz użył tego terminu przenośnie mówiąc o stole ofiarnym z cnót zbudowanym ${ }^{233}$. Do powyższych trzech większych łacińskich Ojców Kościoła trzeba jeszcze dołączyć dla pełniejszego obrazu inne drobniejsze świadectwa, poświadczające używanie terminu mensa w charakterze ołtarza, jak Salwiana z Marsylii, który pod wpływem św. Pawła (1Kor 10, 21) pisał o „mensa dominica” przeciwstawianej „mensae daemonum”234, jak Fulgencjusza z Ruspe, który znów pod wpływem św. Jana Ewangelisty (Ap 6, 9) pisał, że święci Jan i Cyprian są w i pod stołem ołtarzowym ${ }^{235}$, jak dwa starożytne sakramentarze - Sacramentarium Leonianum ${ }^{236}$ i Sacramentarium Gregorianum $^{237}$ nazywające ołtarz „mensa” lub „mensa caelestis”. Warto tu też dodać, że już w literaturze patrystycznej mensa nie zawsze oznaczała cały ołtarz, ale tylko jego część górną - płytę ołtarzową, na której sprawowano Eucharystię: tak czynił np. papież Wigiliusz skarżący się w swoim liście encyklicznym, że gdy był siłą odrywany od ołtarza, spadłaby jego płyta, gdyby nie była podtrzymana rękami duchownych ${ }^{238}$, tak czynił XVI Synod Toledański (693) zalecający m.in., by chleb do konsekracji składany był na płycie ołtarza ${ }^{239}$,

1004: „In mensa igitur Domini et phialae praeparantur et cyathi”; In Hiezechielem II hom. 9, 21, 681, CCL 142, 375: „mensae Domini carnes oblationis portant”; tamże II hom. 9, 22, 730, CCL 142, 576: „quatenus mensae Domini carnes oblationis portent”; tamże II hom. 9, 12, 386, CCL 142, 366: „mensae Domini de quadris lapidibus constructae”.

231 Por. Gregorius Magnus, In Hiezechielem II hom. 9, 483, CCL 142, 269: „Inter haec itaque cogitet, quia mensa Dei est labium intus reflectat”; tamże 568, CCL 142, 372: „Restat ergo ut doctor cum loquitur, quasi mensa Dei semper intus labium reflectat"; tamże hom. 9, 8, 264, CCL 142, 363: „non habent corda itaque sanctorum mensae Dei sunt ad holocaustum ex quadris lapidibus".

232 Por. Gregorius Magnus, Epistolae IV 37, 51, CCL 140, 258: ,, audio eum cum decessore vestro Laurentio ad mensam Ecclesiae per annos plurimos nuncupasse comedisse".

233 Por. Gregorius Magnus, In Hiezechielem II hom. 9, 2, 53, CCL 142, 356: ,in eo mensae ad sacrificium ex virtutibus construuntur".

234 Por. Salvianus Massiliensis, De gubernatione Dei VIII 13, SCh 220, 518: ,illis hoc satis non erat ut cum calice Dei calicem biberent daemoniorum [...] nec sufficiebat ut mensam daemonum mensae dominicae compararent".

235 Por. Fulgentius Ruspensis, Sermo 56, PL 65, 925D: „[Joannes et Cyprianus] ille in mensa, iste sub mensa. Ille in mensa caput perdidit, sed non amisit, iste in mensa non perdidit, sed invenit [...]. Ambo in mensa, sed et ambo sub mensa, qui vidit, inquit, animas iustorum sub ara Dei".

236 Por. Sacramentarium Leonianum, ed. Ch.L. Feltoe, Cambridge 1896, s. 9, 4: ,tuae mensae participes”; s. 85, 25: „mensae”; s. 87, 6: „mensae caelestis”.

237 Por. Ps-Gregorius Magnus, Liber Sacramentorum. Feria IV in hebdomada III, PL 78, 67D: „Sanctificet nos, Domine, qua pasti sumus mensa caelestis".

238 Por. Vigilius papa, Epistola [15] encyclica, PL 69, 55C: „a sancto eius [ecclesiae] altaris tracti pedibus traheremur; et super nos etiam ipsa altaris mensa ceciderat, nisi clericorum nostrorum sustentata".

239 Por. Concilium Toletanum XVI can. 6, Mansi XII 73D: „Quid aliud instituit nos, nisi ut panem integrum sumentes super altaris eius mensam benedicendum ponamus”. 
czy jeszcze późniejszy (769) Kapitularz Karola Wielkiego zakazujący kapłanom odprawiania Mszy Świętej poza miejscem Świętym, a jeśli są w podróży winni to czynić w namiocie i na poświęconej przez biskupa płycie ołtarzowej $(\text { mensa })^{240}$.

W podsumowaniu powyższych uwag można zauważyć, że najpowszechniejszymi nazwami ołtarza w klasycznej literaturze starożytnej były: w greckiej $\beta \omega \mu$ ós, a w łacińskiej ara. Autorzy wczesnochrześcijańscy, ze względu na ich długowieczną treść pogańską, w swoich pismach raczej ich unikali, a jeżeli ich używali, to najczęściej na oznaczenie ołtarzy pogańskich, rzadziej-żydowskich lub heretyckich. W ich miejsce wprowadzili lub upowszechnili nowe, głównie

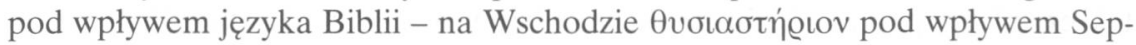
tuaginty lub $£ \varrho \alpha ́ \pi \varepsilon \zeta \alpha$ pod wpływem pism Nowego Testamentu, na Zachodzie zaś altare, jako adaptację klasycznych altaria (rzadziej altarium z późniejszej

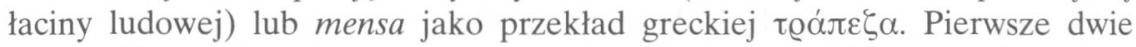
nazwy ( $\beta \omega \mu$ ós i ara), mimo swego zabarwienia pogańskiego, zachowujące jednak swój uroczysty i wiekowy charakter, były nierzadko używane przez Ojców Kościoła również na oznaczenie ołtarza chrześcijańskiego (prawie nig-

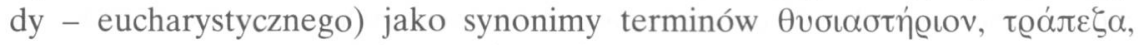
altare czy mensa. Decydujący wpływ miała tu zawsze Biblia: jeżeli starołacińskie jej przekłady oznaczały ołtarz terminem ara, to wczesnochrześcijańscy autorzy komentując ją lub korzystając z jej tekstu, na ogół bez zastrzeżeń tą nazwą się posługiwali.

\title{
DE ALTARIS CHRISTIANI NOMINIBUS IN LITTERIS PATRISTICIS
}

\author{
(Argumentum)
}

Hac in haud brevi dissertatiuncula, quae tribus partibus constat, de nominibus altaris christiani modo philologico tractatur. Priore in parte de vetustissimis altaris classicis praechristianis, deinde de $\theta v \sigma \iota \alpha \sigma \tau \eta \dot{\varrho}$ ra, denique de vocabulis: altare, altarium, ara ac mensa, quae in litteris Latinorum apparent, et haec omnia iam apud antiquissimos auctores christianos (praesertim Patres Apostolicos) inveniuntur, disputatur. In altera autem parte de vocabulis

${ }^{240}$ Por. Capitulare Caroli Magni c. 14, MGHLeges II 46. 


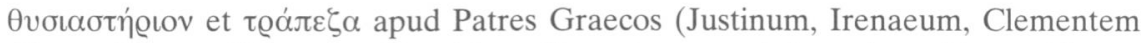
Alexandrinum, Origenem, Eusebium Caesariensem, Athanasium Alexandrinum, Cyrillum Hierosolymitanum, Synesium Cyrensem, Basiliusm Caesariensem, Gregorium Nazianzenum, Gregorium Nyssenum, Joannem Chrysostomum, Dionysium Areopagitam et Joannem Damascenum scrutatur. In tertia denique parte de vocabulis: altare, altarium, ara ac mensa apud Patres Latinos (Tertullianum, Cyprianum, Prudentium, Ambrosium, Sidonium Apollinarem, Optatum Milevitanum, Augustinum, Hieronymum, Petrum Chrysologum, Paulinum Nolanum, Salvianum Masiliensem, Leonem Magnum, Gregorium Magnum, Isidorum Hispalensem et Gregorium Turonensem) enucleatur. 